\title{
A Firm-Level Analysis of Small and Medium Size Enterprise Financing in Poland
}

\author{
Leora F. Klapper \\ Development Research Group \\ The World Bank \\ 1818 H Street, NW \\ Washington, DC 20433 \\ (202) 473-8738 \\ lklapper@worldbank.org
}

Virginia Sarria-Allende

Universidad Austral

Escuela de Direccion y Negocios

Buenos Aires, Argentina

$\leq$ vs189@columbia.edu $>$

\author{
Rida Zaidi \\ Wolfson College \\ University of Cambridge, \\ Cambridge CB2 1TN, UK. \\ rz213@hermes.cam.ac.uk
}

World Bank Policy Research Working Paper 3984, August 2006

The Policy Research Working Paper Series disseminates the findings of work in progress to encourage the exchange of ideas about development issues. An objective of the series is to get the findings out quickly, even if the presentations are less than fully polished. The papers carry the names of the authors and should be cited accordingly. The findings, interpretations, and conclusions expressed in this paper are entirely those of the authors. They do not necessarily represent the view of the World Bank, its Executive Directors, or the countries they represent. Policy Research Working Papers are available online at http://econ.worldbank.org.

The authors thank the Europe and Central Asia (ECA) region of the World Bank for their financial support. The authors also thank Marie-Renee Bakker and Michel Noel for valuable comments. 


\begin{abstract}
:
We test competing theories of capital structure choices using firm-level data on firm borrowings. The majority of firms in the dataset are privately owned, young, micro, or small and medium sized enterprises (SME) firms concentrated in the service sector. In general, the financing pattern of firms is low leverage ratios and, in particular, low levels of intermediated financing and long-term financing. Average firm growth rates decreased dring the five years of the sample period. Average profitability growth ratios are also negative across age and sectors and large firms have the highest negative profit growth rate. Statistical tests find a positive firm size effect on financial intermediation. Larger firms have higher leverage ratios (both short term and long term), including higher use of trade credit. There is also a negative influence of profitability on leverage ratios (more profitable firms use less external financing), which supports the "pecking order" theory that in environments with greater asymmetric information (such as weaker credit information) firms prefer to use internal or inter-firm financing. Finally, firms operating in a competitive environment have higher leverage ratios. For instance, young, small firms are the most active employment generators in the Polish economy. We find overall that SMEs seem to be very active in creating jobs in recent years. This suggests that a new type of firm is emerging that is more market and profit-oriented. But at the same time, these firms appear to have financial constraints that impede their growth. Improvements in the business environment, such as better credit and registry information, could help promote growth in this sector.
\end{abstract}




\section{Section 1: Introduction}

Prior to its transition period, the Polish economy was dominated by large state owned enterprises (SOEs), which employed the largest fraction of the labor force, undertook the largest share of investment activities, and received the largest share of bank financing. However, the liberalization process has provided a major role for small and medium enterprises (SMEs) as a driving force in the transformation of the Polish private sector.

Considering the importance of SMEs in promoting growth and dynamism in transition economies, it is critical to analyze the willingness of the banking sector to lend money to SMEs and the degree to which financial intermediaries have facilitated their development. ${ }^{1} \quad$ Previously, the practice of funding economic activity in transition economies had been mostly directed by the central authorities. It is only after the liberalization process that the banking sector has been able to choose its borrowers and channel a larger share of its funding to companies of different types. ${ }^{2}$ In order to make market based loans, commercial banks were required to measure default risk, which includes firm-level measures of profitability, growth opportunities, and available collateral, as well as country-level risk, such as the efficacy of bankruptcy laws and enforcement. In this paper, we analyze the financial structure of a large sample of Polish firms, hoping to shed light on the firm characteristics that are associated with greater access to financing. These findings can be useful in developing policy recommendations to expand lending to small and new firms.

The paper proceeds as follows. Section 2 reviews previous literature on SME financing and the specific challenges of SMEs in Eastern Europe. Section 3 provides summary statistics of firm characteristics by size, age, region, sector and ownership structure. Section 4 uses regression analysis to test theories of capital structure for a sample of Polish firms. Section 5 concludes.

\section{Section 2: Literature Review}

\section{What is specific about SMEs?}

Many previous studies have analyzed the unique role of SMEs in developed countries. Studies of firms in the United States highlight the importance of SMEs not only as a protagonist for creating new employment opportunities, but also as a source of innovation. Beginning in the 1970s, large manufacturing firms in key industries began to lose their competitiveness, and a number of important empirical studies emerged documenting the role of SMEs in addressing this problem. For example, Acs (1984) discusses how newer and smaller firms entered sectors as "agents of change". Studies using direct measures of innovative activity - based on new products and processes rather

\footnotetext{
${ }^{1}$ For additional analysis of the role of SMEs in transition economies see "SME Financing in Eastern Europe" by Klapper, Sarria-Allende, and Sulla (2003).

${ }^{2}$ See "Commercial Bank Lending to SMEs in Poland" by Melanie Feakins (2004).
} 
than R\&D - have shown that innovative activity is primarily introduced by small firms and not by the larger incumbents (see Acs and Audrestsch, 1988 and 1990). Similarly, Acs and Audretsch (1991) find that smaller firms contribute to greater innovation per number of employees relative to larger firms within the United States. Such findings have also prompted innovation policy studies in transition economies and promotion of the SME sector in general (see Havas, 2002, for Hungary, Lloyd-Reason et. al. 2002 for Czech Republic).

Recent cross-country studies find a strong association between the importance of SMEs and GDP per capita growth, but do not find that SMEs exert a causal impact on growth. Furthermore, the authors find no evidence that SMEs reduce poverty (Beck, Demriguc-Kunt and Levine, 2003). This finding suggests that the impact of the SME sector might vary by country and region.

More recently, there has been growth in literature specifically focusing on SMEs in Eastern Europe. The key difference is that these papers focus on the unique transition process that Eastern European countries have experienced. Unlike SMEs in the United States, many SMEs in Eastern Europe have been created either as a result of the privatization of state-owned enterprises or as new entrants that have emerged after the market liberalization process. Consequently, most studies have focused on the restructuring process that has taken place in transition economies (see Svejnar 2002). For instance, Bilsen and Konings (1998) highlight the job-creation and performance differences among state-owned and de novo private firms. They find that new private firms in selected transition economies were the most dynamic in terms of job creation, and that they widely out-performed state-owned enterprises.

\section{The Financing of SMEs}

The role of finance as a significant contributor to development of SMEs has been an important area of study. Previous literature has examined financing across SMEs and shown that they have different capital structures from larger firms. For example, Cressy and Olofsson (1997) find that smaller businesses have lower fixed to total asset ratios, higher current liabilities relative to total assets, and grater financial risk. Studies also identify the information asymmetries associated with SME lending to explain why it is harder for SMEs to access debt financing. Along these lines, Berger and Udell (1995) find smaller and younger firms are more likely to face higher cost (interest rate) of financing and be required to pledge collateral. Similarly, Satio and Villanueva (1981) and Peel and Wilson (1996) find in general SMEs to have higher costs and reduced access to financing because of the information asymmetries associated with newer, smaller firms.

On the other hand, Scherr, et al. (1990) and Hamilton and Fox (1998) find that smaller companies prefer to limit their issuance of outside equity in order to maintain control. Therefore, most SMEs are structured around concentrated equity stakes, the corporate governance implications of which have been studied extensively. For example, Brush and Chaganti (1998) find ownership structure and creditors rights protection have a significant positive influence on the size and performance of SMEs. Consequently, country-specific factors such as creditor rights and legal efficiency seem to explain the 
unique challenges faced by SMEs accessing external finance: small firms in countries with strong creditor protection are more likely to receive external financing compared to comparable firms that are located in weak legal environments.

\section{SMEs in Eastern Europe}

Looking more closely at SMEs in Eastern European countries, we find a growing body of literature studying financial characteristics and capital structure determinants, either within a cross-sectional setting or in the form of a country-specific analysis.

Among the first group, we find studies that broadly examine financial market development across Eastern Europe. For instance, Gros and Suhrchke (2000) analyze several transition economies and identify the chief similarities and differences across them in terms of the level of financial development, concentration of ownership, and legal and governance standards. A study by the World Bank (2002) examines the early stages of reform and transition to market economy performed by the corporate sector. In particular, it highlights the dynamism of the SME sector in Poland and Hungary, where structural reforms have created a favorable climate for entry of new businesses.

Other studies focus on property rights as a determinant of access to financing for small firms in Eastern Europe. Shleifer (1997) and Frye and Shleifer (1997) show, for instance, that property rights are particularly weak and a severe disincentive to growth in Russia, while this is not the case for Poland, which has relatively more secure property rights than other countries in the region. ${ }^{3}$ Johnson, McMillan and Woodruff (2002) study manufacturing firms in Poland, Romania, Slovakia, Ukraine and Russia based on a survey carried out in 1997 . They find a wide degree of variation across these countries in their access to bank finance as well as in their perceived security of property rights. The authors find the highest percentage of borrowers to be in Poland, with bank financing about 2.3\% of annual sales (the highest along with Russia within their sample of countries). They also find a high rate of reinvestment of profits in Poland, which they explain is a virtue of strong property rights in the country, relative to neighboring economies.

Additional studies, which more directly analyze the determinants of capital structure, find a significant degree of financing constraints faced by SMEs. ${ }^{4}$ The supply of finance seems to be particularly determined by firms' reputation, growth and profitability. Closely related to our study is a paper by Klapper, Sarria-Allende, and Sulla (2002) who use the Amadeus database to analyze patterns of corporate sector development across 15 Eastern and Central European countries during the transition from planned to market economies. This report finds that SMEs seem to constitute the most dynamic sector of the Eastern European economies, relative to large firms. In general, the SME sector comprises

\footnotetext{
${ }^{3}$ It is argued that within country variation in property rights can also exist, influencing access to bank credit (Johnson, McMillan and Woodruff, 2002)

${ }^{4}$ Konings, Rizov and Vandenbussche (2003) find that investment by firms in Poland and Czech Republic is more sensitive to internal financing constraints, as compared to the Romania and Bulgaria case, due to presence of soft budget constraints in the latter. In the same vain, Cornelli et. al. (1996) and Weller (1999) observe that Polish industries have operated under hard budget constraints and were finance constrained during the early stages of the transition process.
} 
relatively younger, more highly leveraged, and more profitable and faster growing firms. This suggests that a new type of firm might be emerging in transition economies that is more market- and profit-oriented. But at the same time, these firms appear to have financial constraints that impede their access to long-term financing and ability to grow.

In addition, there have been a number of World Bank surveys of SMEs in Eastern Europe; e.g. Chaves, Sanchez, Schor and Tesliuc (2001) in Romania and Broadman and Recanatini (2001) in Russia. Other World Bank studies have examined the determinants of capital structure of Bulgarian firms (Budina, Garretsen and De Jong (2000)), Hungarian and Polish enterprises (Cornelli et. al. (1996)), and Romanian (Carare and Perotti (1997)) and Hungarian companies (Colombo (2001)).

\section{Section 3: Data Description}

\section{Firm Distribution}

We use the Bureau Van Dijk "Amadeus" dataset to extract firm-level information on private and publicly owned non-financial Polish firms. The Amadeus database is a comprehensive source of firm-level financial and ownership information, mostly collected from the National Court Register. The data include only limited liability companies and PLC registrations that are required to submit annual filings, and excludes sole-proprietors and partnerships. ${ }^{5}$ The database contains detailed financial and accounting information for each firm, including balance sheet and profit and loss statements, along with other firmspecific data such as year of incorporation, official address, legal form, auditors, number of employees and industry codes. There is also ownership information for the most recent year of data that includes details on the largest shareholders (all shareholders with more than $5 \%$ equity stake), such as reporting name, equity stake and country of origin, as well as details on subsidiaries. It is important to note that the coverage of data in Amadeus is dependent on the successful collection of information by the Polish National Court Register. In addition, the data exclude firms in the informal sector.

Until 1996, Amadeus included predominantly large and listed companies. Since 1998, the coverage of small and medium enterprises has increased substantially. We therefore exclude all years prior to 1998, so as to obtain a balanced number of firms in various size categories within the sample. In addition, we excluded 2003, since data coverage is very sparse. We also drop all firms that have missing assets and sales information, which is critical for creating financing ratios and identifying size categories. Since the study covers the years 1998-2002, the number of observations varies significantly during the period, going from 5,757 observations in the year 1998 to 15,315 in the year 2002 .

\footnotetext{
${ }^{5}$ Sole-proprietors and partnerships are required to register with local municipal offices. The owners are required to file the name of the firm and the names of owners, although this information is kept confidential. In addition, firms must file annual tax receipts, which certify that taxes have been paid and that the firm continues to exist. Creditors may inquire only whether the firm is registered and has paid its taxes. No financial information or current ownership information is filed.
} 
We determine size using the official EU definitions on micro, small, medium and large firms. The EU definitions provide two classifications: by number of employees and the value of total assets and sales. We do not use the former due to limited information on the number of employees provided by Polish firms. According to the latter definition, we identify as "micro" firms with total assets or sales less than 2 million euros; "small" as with total assets or sales less than 10 million euros; "medium" as firms with either total assets less than 43 million euros or sales less than 50 million euros; and "large" as firms with total assets greater than 43 million euros or sales greater than 50 million euros. ${ }^{6}$ Based on this definition, about $35 \%$ of the sample consists of micro firms, while an additional $62 \%$ of firms can be classified as SMEs. Large firms constitute only less than $4 \%$ of the total sample (see Table 1A).

We also split the sample according to four age categories: 0-1, 2-5, 6-10 and more than 10 years since incorporation. Overall, the firms in our sample can be considered relatively young - almost $30 \%$ of firms were created during the last 5 years, as can be expected in transition countries, and about $60 \%$ of all firms have only lived for less than 10 years. Furthermore, about $60 \%$ of large firms are older than 10 years. Nevertheless, it is surprising to find that more than $22 \%$ of micro firms have also been in existence for more than 10 years.

Table 1A also disaggregates data by region, legal form, listing and industry type, as well as for the year 2002. As shown in Table 1A, our sample includes a large majority of services and manufacturing firms (60\% and $38 \%$, respectively). The remaining $2 \%$ of firms are mostly agricultural. Although agriculture is an important sector in Poland, the industry appears to be dominated by individual farmers and a few large agribusiness corporations. An interesting feature of the data is the higher concentration of smaller and younger firms in the service sector, in contrast to the relatively larger and older firms that seem to characterize the industrial sector. This may relate to the fact that during the Soviet era the service sector was underemphasized and almost non-existent; therefore, it is likely that this sector may have provided the greatest opportunities for new entrepreneurs. In addition, firms might be attracted to the low costs necessary to enter many service sectors versus the difficulties for new firms to access the long-term financing necessary to purchase the equipment and machinery needed to enter the manufacturing sector.

We also find that over $60 \%$ of firms in our dataset are limited liability partnerships, of which $76 \%$ are micro and small firms, an additional $20 \%$ are joint-stock companies, and the remainder are categorized by the Polish government as 'non-classified'. We identify three main regions, where almost $50 \%$ of the sample is located: Wielkopolskie, Slaskie, and Mazowieckie (the largest representation of firms with about $26 \%$ of the sample). Other regions are grouped in the "other" category. In the following chapters we analyze the role these firm-level variables play in explaining the dynamics of SME growth and financing.

The ownership categorization is extracted from data available for the largest owner 'type', i.e. whether the owner is foreign, government, or a domestic company or individual . Over half of the firms within the sample are privately owned, while the rest are evenly split

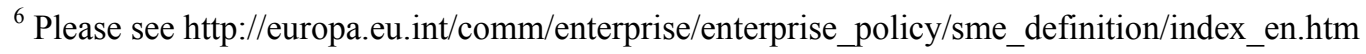


between foreign and governmental ownership. We observe that large firms are owned either by the government or by a foreigner (local private investors own only $6 \%$ of large firms). Moreover, $85 \%$ of firms owned by private investors can be classified as either micro or small firms. Medium firm ownership is more evenly distributed $(35 \%$ foreign owned, $27 \%$ in the hands of the government and $38 \%$ privately held).

Table 1B shows summary statistics by ownership structure. It must be noted that ownership information becomes more widely available as we move from micro to large firms. Although there are only few cases of firms which are wholly-owned domestic subsidiaries, we observe considerable participation of wholly-owned foreign subsidiaries in the sample. ${ }^{7}$ This approximates $6 \%, 9 \%, 15 \%$ and $19 \%$ for micro, small, medium and large firms respectively. We find that $40-50 \%$ of firms with non-missing ownership information have a single domestic shareholder with a stake larger than $50 \%$ (i.e. majority shareholder). On the other hand, more than $20 \%$ of firms have a majority foreign shareholder (this percentage is smaller for the micro firms and grows along with firm size). This implies that $65 \%$ of the sub set of firms with non-missing ownership information, has one majority owner, either domestic or foreign.

Among investors with absolute majority stakes, we can further identify whether they are state, individuals or industrial shareholders. Larger and older firms are primarily held by the state. About $40 \%$ of large firms have the state as a majority shareholder; another $25 \%$ of those firms, however, have an industrial majority shareholder. Individuals, on the other hand, are majority shareholders of about $45 \%$ of micro firms, but hold a majority stake only of less than $9 \%$ of large firms. Individuals also hold the greater proportion of newborn firms that have a majority shareholder.

Combining sector and ownership information, we find that the vast majority of agricultural firms are held by domestic shareholders (about 70\% of the subset for which ownership information is available), and, more specifically, by a state majority owner (about 55\%). In comparison, firms in the industry and service sectors are more likely to be private individuals or corporations. We further notice that most industrial majority owners are foreigners, while most individual investors are domestic.

\section{Summary Statistics}

Table 2 shows summary statistics for 2002. Even though the firms in our sample are mostly young (with a median age of 9 years) and small (median total assets in PLN equal to 8,704), they exhibit significant positive growth rates. The median growth rate is about $5 \%$, although a number of high-growth firms cause an average asset growth is about $17 \%$ a year.

A potential concern could arise, however, by looking at the low employment growth rate. Both median and average employment growth rates are zero. Moreover, at least $75 \%$ of the sample reveals zero employment growth rates at the year 2002. This is a potential

\footnotetext{
${ }^{7}$ Where wholly-owned domestic (foreign) firms are defined as $100 \%$ owned by one domestic (foreign) industrial shareholder.
} 
alarm since the SMEs represented in the sample are supposed to be the most dynamic and, consequently, the greatest contributors to the generation of employment opportunities.

The sample also shows that firms maintain low leverage ratios. Intermediated financing represents only $2 \%$ of assets for the median firm (11\% on average), which is remarkably low. This debt is highly concentrated on the short run, which may imply either that there is very little access or a lower demand for long-term financing. On the other hand, we observe that firms receive financing from suppliers: account payables represent $19 \%$ of assets ( $27 \%$ on average). Finally, even though institutional financing is remarkably low, our firms exhibit (median) liabilities to total assets ratios of about $61 \%$. This is likely to be explained partially due to the effect of account payables, but also to the inclusion of other non-intermediated financing, reported as either other current or other non-current liabilities (probably connected to overdue liabilities to the state).

More than a quarter of the firms in our sample are unprofitable. The average gross margin is actually equal to zero. The return on assets for this group is about $5 \%$ a year, which could be considered quite low. An important caveat to performance data, however, is that firms may intentionally under report profitability in order to avoid taxes.

To summarize, we find firms exhibiting average weak performance, low use of (access to) financing, low employment generation, but high growth (in terms of either sales or assets). To understand this cocktail, we will expand our analysis by looking at summary statistics by size, age, sector, and ownership structure. Finally, we will introduce some more sophisticated techniques, which can deepen our analysis of firms' financial structures.

\section{Summary Statistics by Size}

Table 3A summarizes firm characteristics by size categories. We first observe is that age is increasing in size; i.e. larger firms tend to also be older. The average age for the group of micro firms is between 8 and 9 years old, while it is close to 34 years old for the large firms group. This difference is statistically significant. The fact that recently incorporated firms are much smaller than older firms is likely to be connected to the development of the SME sector since the liberalization of the business environment, and the assistance of a multitude of international programs. The growth of the SME sector in the post-communist countries has been heralded as one of the prominent success stories of East European economies. ${ }^{8}$

Next we observe that the growth rate of employment is increasing in size. Moreover, in the aggregate, both micro and small firms exhibit insignificant employment growth rates; that is, firms are keeping steady or decreasing employment throughout the sample period. This result may be explained by financing constraints that SMEs face when looking for to finance their growth, or rather, to a low employment requirement on their specific growth (since SMEs are largely concentrated in the service sector).

Pissarides (1999) showed that credit constraints limited the growth of SMEs in the CEE countries during the 1990s. We also see in our sample that firms do not have access

\footnotetext{
${ }^{8}$ See Levitsky (1996) and the OECD (1996).
} 
to long-term funds, but most financing is concentrated in the short run (unless we assume that firms voluntarily decided not to borrow long-term). Additionally, we find the use of trade credit to be monotonically decreasing in size, which may also signal low access to intermediated credit. Micro firms, for example, finance $31 \%$ of their assets using credit from suppliers; while large firms finance only $18 \%$ of their assets with this alternative. This difference is also significant at the $1 \%$ level. We also observe that the SME sector has grown in terms of assets and sales, which shows some investment capacity. We will deepen our understanding of these patterns by looking at the information classified also according to age categories.

Somewhat surprisingly, we find that smaller firms tent to be more liquid; the current ratio for both micro and small firms is substantially higher than the corresponding level in large firms, and this difference is statistically significant at conventional levels. This may imply a sort of "precautionary" capital structure, given that smaller firms might suffer more credit rationing when trying to get auxiliary funding from institutional sources. In the same vain, we observe that smaller firms have a much lower percentage of firms with coverage ratios below 2; in general, coverage ratios less than 2 suggest a higher risk of credit default. We find that coverage ratios increase with size, with the corresponding percentage for large firms being almost twice as high as the one calculated for the sample of micro firms. Lastly, we cannot be conclusive when approaching profitability issues. Smaller firms do not significantly differ in terms of profitability from the subset of larger firms.

\section{Summary Statistics by Age}

Table 3A shows firm characteristics by age categories. We observe that in general, new firms experience much higher growth rates. Our three alternative proxies for growth (measured by growth of assets, sales and employment) are monotonically decreasing in age. One important conclusion we can get from this observation is that even though we do not find that, on average, SMEs contribute to the creation of job opportunities, younger firms (which tend to be mostly micro and small firms) do contribute to job creation. For example, micro firms have an employment growth rate of $27 \%$, while firms of more than ten years since incorporation exhibit a negative $3 \%$, and the difference is statistically significant at the $1 \%$ level. We can conclude from this observation that SMEs may have not generated employment opportunities in the past, but that they seem to have been very active in creating jobs in the most recent years.

We also observe that younger firms use significantly higher trade credit financing and provide more credit to their customers. Additionally, younger firms enjoy a healthier financial position; the percentage of firms with coverage ratios below 2 is significantly smaller for new firms and increases along with firms' age. Finally, profitability does not seem to be statistically related to age.

\section{Summary Statistics by Ownership}

Table 3B identifies three main ownership categories: foreign, government and private. As one might expect, we find that state owned enterprises (SOE) are the oldest 
firms within the sample. In addition, SOEs are significantly larger than other private domestic firms and employ a much larger work force. Nevertheless, SOEs exhibit the lowest growth rates among all firms we consider. In particular, they experienced a negative employment growth rate in 2002. This suggests that although SOEs were the largest employees in previous years, this may not be the case in the future.

Another feature of SOEs is that they show the lowest leverage ratio among all ownership categories. This applies to both institutional and commercial financing. If we compare foreign versus domestic private firms, we observe that the latter are younger and smaller. At the same time, local private firms exhibit somewhat higher leverage ratios and significantly higher profitability.

SOEs also experienced negative - and the lowest - profitability in 2002. Foreign and private domestic firms, on the contrary, show significantly positive gross margins and return on assets for the same period. The low profitability of SOEs may be related to their choice (or availability) of external financing; but we will postpone this investigation until the next section.

\section{Summary Statistics by Legal Type}

We also contrast firm characteristics by legal types; more specifically, we compare limited liability partnerships (LLP) to joint-stock companies. We find the latter to be older and significantly larger than LLPs. We find that joint-stock companies experience much lower growth rates in terms of sales, assets and employment. Moreover, join-stock companies exhibit negative average employment growth rates. LLPs, on their part, distinguish themselves by their intense use of trade credit financing. Finally, LLPs exhibit substantially higher profitability ratios.

\section{Summary Statistics by Sector}

Table 3C identifies firms as operating within three broad sectors: industry, services and agriculture. Industrial firms appear to be, in our sample, significantly older as well as larger than other firms. They have greater assets and sales and employ a much larger work force. In addition, industrial firms seem to exhibit a more compromised financial position: a higher percentage of them present low coverage ratios (below 2) and appear to be suffering greater liquidity constraints. An explanation may be that many manufacturing firms are privatized large firms coming from the Soviet era, when the service sector was underemphasized. According to some studies on privatized firms in transition economies (for example, Harper, 1999), relatively larger firms face more difficulties in improving performance after privatization.

None of the identified sectors, in the aggregate, seems to be creating jobs in the year 2002. Furthermore, agricultural firms exhibit negative employment growth rate for that year. In regard to financing structures, we find that agricultural firms rely more on intermediated financing and access to long-term finance; however, as previously mentioned, leverage ratios are generally low across all sectors. The ratio of debt to total assets is merely $12 \%, 10 \%$ and $17 \%$ for the industry, service and agricultural firms, respectively. Firms in the service sector make the highest use of trade credit. 


\section{Summary Statistics by Region}

We also identify three main regions. By looking at the financial ratios by region (for the year 2002), we observe that firms in Wielkopolskie (that includes Warsaw) use both more intermediated financing and trade credit. These firms also seem to have higher profitability ratios, reaching ROA of $6 \%$ (rather than the $4 \%$ observed in the other two identified regions).

\section{Evolution of Firms' Characteristics over Time}

Table 4 shows financing ratios by year. By looking at the unbalanced sample we observe that the average size (as well as the median size) of firms tends to be mostly decreasing across years (presenting a peak in 1999). However, when we look at a constant sample (i.e. that includes only firms that are included in the database in all years), we find firm size to be actually increasing over time. This implies that, on the one hand, the firms staying in the sample for the whole period are becoming larger as they age. On the other hand, however, new firms entering the sample during this 5-year time span are remarkably smaller than those incorporated in the previous years. This is all consistent with the expected dynamic of a transition economy.

Along the same lines, if we look at the constant sample results, we observe that the percentage of micro firms within the sample decreases over time; the same happens with the sub group of small firms. This implies that both micro and small firms actually migrate to larger categories over time. However, by looking at the unbalanced sample, we observe that more start-ups are being incorporated into the sample over time: the percentage of firms with less than a year since incorporation changes from $1.2 \%$ to $6.1 \%$ in five years

We do not observe a clear trend regarding the use of intermediated financing over time. However, we do find that trade credit (both used and provided) increases across years, as does the ratio of total liabilities over assets (both in average and median terms). Firms in the sample seem to be shortening debt maturity for the later periods, which, together with the increasing liquidity constraints (proxied by lower current ratios), could indicate a weaker financial condition for the average firm. This result is also consistent with the fact that the percentage of firms with coverage ratios below two almost doubles in the five-year period.

We find that most services firms have been incorporated within our sample period. This sector represented half of the sample in 1998, but close to $60 \%$ of total firms in 2002 . Finally, incoming firms are mostly structured as Limited Liability Partnerships.

\section{Evolution of Firm Characteristics by Size}

Table 5 shows the evolution of firms by size categories. After noticing that mostly micro and small firms enter the sample during the period, we now observe that incoming micro firms are also smaller and younger compared to those already incorporated within the size category in previous years. These new firms also tend to make higher use of trade credit financing and report higher liabilities to total assets ratios. On the other hand, while

we do not find that micro firms as a group (as seen in the unbalanced sample) exhibit a 
deterioration of their financial condition over time (neither the current ratio nor the percentage of firms with interest coverage below 2 cause particular concerns), we observe that the sub-group of firms that remains in the sample for the whole period do exhibit a worsened financial condition, materialized in a much higher percentage of potentially distressed firms (growing from about $20 \%$ to close to $60 \%$, on average), and lower profitability ratios. This may imply that the economic transition could be creating an environment that favors the creation of new healthy micro firms, but does not support the transition of former SOEs.

In summary, we find that all firm categories face more compromised financial conditions and lower profitability ratios over time and that the problem is more acute if we focus on the subset of firms that remains in the sample for the whole period. Firms that have been incorporated into the dataset during the sample period are generally smaller, younger and exhibit slightly healthier financial conditions.

One may wonder if this deteriorated financial and profitability pattern found at the aggregate level is the consequence of having one sector or sub-group of firms facing particular difficulties, or rather, a more general phenomenon. To answer this question we undertake a more detailed analysis of firms' financial evolution by sector and age category. The results are shown in Figure 1.

We find that firms in all sectors are growing over time, with manufacturing firms being the largest on average within the sample (measured by firms' total assets). We also observe that all firms that are more than one year old have grown over the years. In addition, all sectors have exhibited a decline in their use of intermediated financing during the last few years. Furthermore, debt maturity seems to also be decreasing for all sectors and years, although the use of debt financing is almost constant across age and year categories. Finally, we confirm that the deteriorated financial and profitability condition we find on average is also present when looking at sub-samples by either sector or age categories.

\section{Patterns of Firms' Growth}

Table 6 examines growth rates, by year, focusing on three firm characteristics: size, profitability and financial structure. To measure growth rates we work with a constant sample, and present both mean and median figures. We also include the mean and median growth rates for the year 2002, computed using all the available information (i.e. the unbalanced sample).

We observe that firms' average growth (measured either by total assets or sales) is consistently positive in each single year we consider, yet, growth rates are somewhat decreasing over time. For example, even though the average total assets growth rate is more than $25 \%$ for the year 1998, it falls to less than $10 \%$ after five years. This pattern is also found across size and sectors; nevertheless, manufacturing firms generally present smaller average growth rates than those exhibited by the service sector.

Next, we find that profitability growth ratios are negative across all sector and age sub-samples. Moreover, taking the sample as a whole, we find that profitability growth 
ratios have become increasingly negative over time. The ratios are still negative but much more moderate if we concentrate on median rather than mean indicators; implying that the average negative profitability growth rates we observe are strongly influenced by some particularly unprofitable firms. When we compare profitability growth rates across firm sizes, we find that despite the fact that small firms were the ones suffering the largest negative profit growth rates at the beginning of the sample period, the most negative indicators are found among the medium and large sub-groups during the later years. Finally, looking at profitability growth rates across sectors, we find again a consistent pattern of negative growth rates for each category, with the service sector exhibiting the most dramatic decrease.

To conclude our sample description we examine growth rates related of alternative financing choices (such as trade credit, bank financing or other sources). For the overall balanced sample, we find that leverage ratios exhibit positive growth rates in each of the sampled years. However, figures tend to decrease over time (except for a small recovery in 2002); that is, leverage increases at a decreasing rate. This positive growth rates in leverage ratios is somehow biased towards intermediated financing for the first three years, but moves towards trade credit financing at the end of the sample period. This is exactly the case regardless of whether we look at small, medium or large firms. Also, the same pattern is observed both for the manufacturing and service sectors.

\section{Section 4: Multiple Regression Analysis of Firms’ Capital Structure}

The previous section provides summary statistic that has helped us characterize the different groups of firms represented in our sample. However, to deepen our understanding of firms' capital structure decisions, this univariate analysis is limited. Since the channel through which firm characteristics influence financing decisions could be quite complex, it is necessary to observe these relationships in a more synthesized fashion. This can be achieved only with a multiple regression analysis.

\section{Understanding Firms' Capital Structure Decisions}

We begin with predictions of the most well known capital structure theories, which are found in the financial literature. The Modigliani-Miller (1958) work on irrelevance of capital structure on investment decisions has spurred a wide-range of literature covering the determinants of capital structure. The two most prominent theories that have emerged are the Pecking Order Theory of finance (Myers and Majluf, 1984) and the Trade Off Theory (DeAngelo and Masulis 1980).

We can start by presenting the predictions of the Static Trade Off Theory (STOT) of capital structure. The STOT states that firms determine optimal debt-equity ratios by borrowing up to the point where the marginal value of the benefits derived by financing with additional debt (tax advantage of interest deductibility/ tax shield ${ }^{9}$ ) is just offset by the

\footnotetext{
${ }^{9}$ Modigliani F and Miller M., Corporate Income Taxes and the Cost of Capital: a Correction, American Economic Review, 53,433-443. Modigliani F and Miller M, 1958, The Cost of Capital, Corporation Finance and the Theory of Investment, American Economic Review, 48
} 
increase in the present value of possible costs associated to financial distress ${ }^{10}$ (see Miller 1977).

All the same, this theory expects leverage to be positively related to size (inverse proxy for volatility and cost of bankruptcy); profits (more profits that need to be protected from taxation and lower expected cost of financial distress); and tangibility of the firm's asset structure (again, lower bankruptcy costs). Alternatively, high growth opportunities imply a higher cost of financial distress (the value of growth opportunities, which depend on future investment decisions, is a poor collateral), suggesting less debt usage. This view also predicts lower debt to asset ratios by firms which already enjoy other non-debt tax shields (NDTS).

A different view of capital structure decisions could be highlighted when we take into account the existence of asymmetric information: managers or insiders are assumed to count on superior information; more specifically, they are supposed to have a better judgment about the firm's future cash flows or investment opportunities.

The main approach arising from asymmetric information settings is known as the Pecking Order Theory (POT) of financing hierarchy, which presupposes firms do not target specific debt ratios; only if internal funds are insufficient they would then turn to external financing. The reason behind this behavior is that external financing is costly under informational asymmetries between management and investors. Myers and Majluf (1984) describe a story in which entrepreneurs who are currently managing some assets need to raise funds for undertaking a new project whose profitability is known only to them. If managers act in the interest of old passive shareholders, they may pass up some positive NPV investment, avoiding issuing shares at a bargaining price. Potential investors, knowing about these incentives, take the not-issuing event as a good symptom and the issuance of new shares as a bad sign. Under this scenario of asymmetric information affecting firm's issue-invest decisions, the authors introduce the concepts of the POT. This theory predicts that firms would rely first on internal other than external sources of funds and, when external financing is needed, they would prefer to issue the safest security first i.e. debt-, before equity. Even though the availability of risk-free debt financing would make the described problem disappear, risky debt only gets to alleviate the problem reducing the states of the world in which a positive NPV is passed up.

According to the POT more profitable firms borrow less, not because their target debt ratio is low -in fact they do not have a target-, but because profitable firms have more internal financing available. Myers and Majluf suggest that firms seek to maintain financial slack to avoid the need for external funds. Also, firms with a more tangible asset structure are more able to issue low-risk (collateralized) debt, and consequently, would tend to have a higher share of debt in their optimal financial structure.

\footnotetext{
${ }^{10}$ Costs of bankruptcy or reorganization that arise when firms' creditworthiness is in doubt. The sole prospect of financial distress can drag down the current market value of the firm. Financial Distress, however, is usually understood as the probability of entering financial distress times the cost per se.
} 
Eastern European firms are an ideal sample to test this theory, since many countries suffer from weak transparency and disclosure requirements, and poor accounting standards that exacerbate the information asymmetries.

The last theory of capital structure we consider is related to Agency Conflicts. Two types of conflicts are to be analyzed: those between bondholders and equityholders and those involving managers and equityholders. Conflicts between debt and equity holders arise when there is risk of default. It is argued that shareholders may "underinvest" -and pass up positive NPV projects if they perceive profits will be used to pay off existing debtholders. This conflict implies that firms will tend to minimize debt or use short-term debt in order to limit underinvestment costs. This cost is more significant among highgrowth firms, i.e. those have more to lose (Myers 1977). Consequently, we would expect to find high-growth firms exhibiting lower (long-term) debt to assets ratios.

On the other hand, value can also be transferred from creditors to stockholders in the face of asset substitution: highly levered equityholders may choose risky investments, given that the high returns that could be reached in the "good states", may avoid the firm falling into financial distress; if things happen to go wrong, there is not much to lose, anyway. Given that the longer the firm's history in repaying its debt the better is its reputation, we can expect that older, more established firms, would find it optimal to choose safer projects (ie. avoiding engagement in asset substitution strategists that could lead to losing a valuable reputation ${ }^{11}$ ). Firms with long track records will have lower default rates and lower costs of debt than firms with brief histories (Harris and Raviv, 1991).

The second kind of conflict is the one that arises between managers and equity holders given that managers are believed to favor perk consumption or make inefficient investment decisions at the expense of shareholders (Jensen 1986). This problem is bigger if the firm has ample free cash flow and lower growth opportunities. Since higher debt reduces the equity agency cost, bringing about a greater threat of bankruptcy, monitoring from creditors, and lower available free cash flow, it reduces managerial tendency to engage in expropriation of private benefits (Grossman and Hart 1982); consequently, profitable low growth firms are likely to choose higher debt ratios in order to mitigate this problem. Greater concentration of ownership should be associated with lower debt agency costs due to lesser divergence between managerial and owner interests. Kim and Sorensen (1986) suggest that this implies that firms with concentrated ownership will have higher debt ratios.

\footnotetext{
${ }^{11}$ Diamond R., 1989, Reputation Acquisition in Debt Markets, Journal of Political Economy, Aug. 1989, Vol 97
} 
We summarize the predictions of capital structure theories in the following table:

\begin{tabular}{|l|c|c|c|c|c|c|c|}
\hline Leverage & Size & Age & Profits & Growth & Tang & NDTS & $\begin{array}{c}\text { Growth } \\
\text { Opportunities }\end{array}$ \\
\hline \hline Static Trade Off & + & & + & & + & - & - \\
\hline Peking Order & & & - & & + & & \\
\hline Agency Conflicts & & & & & & & \\
\hline Equityholder - Bondholder & & $\begin{array}{c}+ \\
\text { If reputation }\end{array}$ & & & + & & - \\
\hline Equityholder - Manager & & $\begin{array}{c}+ \\
\text { To } \\
\text { mitigate }\end{array}$ & & & & - \\
\hline
\end{tabular}

Much of this literature has been empirically tested, but there is no wide consensus on the relevant determinants of capital structure. ${ }^{12}$ Fama and French (2002), Rajan and Zingales (1995), Titman and Wessels (1998) among others, find that each of the theories has some explanatory power and no one can be fully rejected. Booth et. al (2001) also find similar relationships when they extend their results to developing countries; they fail, however, to take into account the institutional, legal and accounting differences. More recent extensions have introduced the institutional and legal environment as factors determining debt levels (Demirguc-Kunt and Maksimovic (2002), La Porta et. al (1998), among others). As a result, the factors that have traditionally been used as determinants within the setting of developed countries, may not apply in the same fashion when considering a country with a wholly different institutional environment. This is our interest in analyzing the determinants of capital structure in one particular case: Poland.

While most of the above studies focus on large publicly-quoted firms, some literature also specifically examines capital structure determinants among SMEs. As previously mentioned, a paper by Cressy and Olofsson (1997) finds that smaller businesses are more financially risky and consequently face higher difficulties in accessing external finance; at the time Scherr, et al. (1990) and Hamilton and Fox (1998) suggest that smaller companies limit their issuance of outside equity in order to maintain control. We will analyze how these incentives work in the case of Poland.

From the supply side, Egerer (1995) analyzes bank lending in the Czech Republic. He finds that firms have difficulty borrowing, since corporate performance is not transparent and weak creditor rights and collateral laws discourage collateral-based lending. He suggests that ownership connections between banks and firms could be beneficial in transition economies to overcoming information asymmetries and weak laws. Although we cannot identify the strength of the bank-firm relationship, we do get to some conjectures on the supply side story of capital structure in Poland.

\section{The Capital Structure of Polish Firms}

We now analyze what determines (what explains) the financing decisions of Polish firms. To accomplish this, we need to examine which characteristics of these firms seem to be regularly connected with specific choices in the financial structure.

\footnotetext{
${ }^{12}$ See Harris and Raviv (1991), Titman (2001) and Welch (2004) for reviews of capital structure literature.
} 
We concentrate our regression analysis in the three size categories for which the information is more adequate across our sample period: small, medium and large firms (i.e. we drop micro firms for this part of the analysis); and we cover the same sample period we have been exploring in our summary statistics analysis (i.e. 1998-2002).

The study begins with two common specifications: Table 7 shows pooled OLS and fixed effects regressions. Fixed effects regressions allow us to observe how time-varying firm characteristics explain financing decisions, after accounting for the impact of those features (not included, maybe even not clearly identified) that are fixed over time. We compute four alternative dependent variables to help us better understand financing decisions. We define total debt, short-term debt, long-term debt, and payables ratios, all scaled by total assets.

We observe that size (proxied by the log of firms' sales) is positively related to all of our dependent variables. That is, larger firms seem to have higher leverage ratios; not only intermediated financing (both short and long-term), but also trade credit. This result is only evident in our pooled OLS specification, perhaps because there is little variability in firm sizes, so that the influence of size is not captured in the fixed effects model (where only the coefficient of trade credit remains positive and statistically significant). This result is consistent with the STOT, according to which larger firms are considered to be subject to lower bankruptcy costs.

Another interpretation for this finding is provided by Dević and Krstić. ${ }^{13}$ They consider that size might not be a proxy for bankruptcy costs but a proxy for the strength of the firm-supplier relationships. Given that a system of intercompany relationships is likely to subsist after a decentralization process, and that larger firms might be more active in that system, the authors suggest a positive correlation between size and leverage to be a natural result.

Some models include firms' age as one additional explanatory variable of firms' financial choices. Particularly, we see that under the agency view, age is commonly taken as a proxy for firm's reputation (interpreting that older firms usually have longer financial records and therefore, enjoy better access to debt financing). Following this approach, age should be positively correlated with firm's leverage ratios. However, this is not what we observe. We find statistically significant negative coefficients; that is, older firms exhibit lower leverage ratios.

A potential interpretation for this finding could be that in the context of a transition economy, such as Poland, to be old actually does not imply to be good; or, in other words, a long record does not necessarily imply a good record. Consistent with this conjecture, in our descriptive analysis we observed that younger firms actually enjoy healthier financial positions: a lower percentage of firms in this category exhibited coverage ratio below 2, which is often considered a given critical value of risk by lenders. So, our results suggest

\footnotetext{
${ }^{13}$ Dević A and Krstić B, 2001, Comparative analysis of the Capital Structure determinants in Polish and Hungarian Enterprises, Empirical Study. Facta Universitatis, Economics and Organization Series, Vol. 1, No 9, 2001, pp. $85-100$
} 
that once we control for other firms' characteristics, new and younger firms are more likely to access more credit financing.

We include the return on assets (ROA) in all regressions as a proxy for profitability. This measure presents a negative influence in all four alternative dependent variables. This implies that more profitable firms tend to rely less on financing by third parties. The reason for this behavior could be explained by the POT of capital structure, according to which firms prefer to start covering their financing needs through the use of instruments that are less subject to asymmetric information problems. Since retained earnings is the least sensitive source of financing, more profitable firms (generating higher cash flow) may choose to postpone the use of debt financing until they exhaust internally generated funds; consequently, they tend to exhibit lower leverage ratios in their optimal financial structure.

The fact that firms' profitability is negatively associated with leverage ratios, on the other hand, goes against the predictions of the STOT. Another reason for this could be that in the polish case, the existence of non-debt tax shields, tax breaks or various incentives (ie. Special Economic Zones ${ }^{14}$ ) may reduce the attractiveness of debt financing in achieving tax advantage from interest deductibility. Alternatively, given that the Warsaw Stock Exchange was not opened until 1991, and that it remains small in regard to market capitalization, it is not surprising to find good grounds for the POT to be (more) at work. Firms are likely to rely on a sort of hierarchy model, exhausting first all sort of internally generated funds, and postponing equity issuance until all the available (expensive) bank credit has been used.

Another firm characteristic we include is the ratio of fixed to total assets. This ratio is commonly understood as a tangibility measure; that is, it expresses the collateral capacity of a given firm. As previously discussed, the STOT of capital structure predicts that firms with greater collateral value recognize a lower potential cost of financial distress and, consequently, find it optimal to choose a higher share of debt in their financial structure (demand side). Consistent with this view, we find that the ratio of fixed to total assets is positively related to the firms' debt to asset ratio. Moreover, the higher this tangibility measure is, the greater the long-term debt to asset ratio firms report; and, somewhat conversely, the higher the tangibility ratio, the lower the share of short-term debt and trade credit share within the firm financial structure.

An alternative interpretation for this finding may be taken from a supply side consideration. This positive connection between tangibility (as well as size) and firms' leverage ratios may simply imply that Polish firms that can offer better collateral, can more easily access to long-term financing; at the time that those with less collateral to offer can only rely on short-term debt.

\footnotetext{
${ }^{14}$ Law on Special Economic Zones of 20 October 1994 creates the grounds for establishing and operating Special Economic Zones (SEZ). It provides the investors operating in the zones with various incentives and tax breaks. The most important ones remaining in force in 2001 include a partial or a complete exemption from corporate income tax of revenues coming from business operations carried out in a given zone and counting some part of investment expenses as an income-generating cost. There are two Special Economic Zones in Slaskie: Katowice and Częstochowa.
} 
Our regressions also show that firms exhibiting higher growth base a superior share of their financial structure on debt. This result is somewhat surprising, if we try to interpret it under the agency view. The Agency story predicts that high-growth firms will be likely to reduce their reliance on debt financing in order to maintain certain financial flexibility for the time when financing needs (likely to arise in case of high-growth firms) come up. Moreover, the agency view also suggests that high-growth firms will more likely rely on short-term (rather than long-term) debt, in order to maintain the capacity to change the financial structure when it becomes optimal to do so. Our results are also opposite to this conjecture, since we find that those firms experiencing higher growth rates actually use more long-term financing (and do not differentiate from the rest in their use of short-term debt). This positive link between firms' growth and the use of intermediated (long-term) debt and trade credit financing can be interpreted as follows: both banks and suppliers choose to finance high-growth firms, to share in their future favorable business conditions, but at the same time they are reluctant to lend money to non-growing firms (a supply effect).

The STOT, as was previously discussed, suggests that firms look for debt financing in order to take advantage of the tax shield derived from the tax deductibility of interest expenses; however, a firm already enjoying other sources of tax shields (e.g. depreciation), may be less willing to take on debt. We test this conjecture by introducing a measure of non-debt tax shields (NDTS) in our regression model; basically, we compute the ratio of depreciation to total assets, and find that this measure is positively related to the short-term debt to assets ratio (contrary to the prediction of the STOT). However, once we control for firms' fixed effects, we obtain the expected negative connection between these NDTS and both debt and long-term debt to asset ratios.

The last variable included in the general basic model is a measure of industry concentration (computed as the sum of the 5 largest firms' total sales divided by the total sales in the industry). We find a positive association between industry concentration and firms' use of intermediated (long-term) debt. One can expect that firms operating in a competitive environment would be subject to a competitive pressure that eventually would lead to better performance, making them attractive for financing. Estrin et al (2005) find evidence that domestic competitive pressure is associated with better firm performance, measured as total factor productivity (TFP), especially in Poland. We may also think that more competitive environments lead firms to struggle more to differentiate from their rivals and, consequently, to generate a better reputation (which allows them to access better financing terms -again, a supply effect).

Next, we consider a new specification (reported in Table 8) where we incorporate three subsets of dummy variables to our pooled OLS regressions; these three groups are meant to identify size (small and medium, with large being the omitted category), ownership (foreign and government, with private domestic firms as the omitted variable), and region (keeping "other regions" unspecified). We do not run here the fixed effects model, since our new explanatory variables would all drop from the regressions, being fixed over time. 
The first thing we observe is that although SMEs do not significantly differentiate from large firms in their aggregate leverage ratios (we omit reporting a regression having total liabilities as the dependent variable, which does not significantly differ by size ${ }^{15}$ ), they do maintain significantly higher short-term debt and account payables to assets ratio. Regarding foreign firms, we find that they use significantly higher intermediated (mainly long-term) financing; at the time they seem to maintain significantly lower credit from suppliers. Another result indicates that governmental firms maintain significantly lower leverage ratios (both short- and long-term debt). From a regional perspective, we do not find much variation on financial patterns among the regions we identify. Long-term financing seems to be more intensely used in the Mazoweicke region, at the time that firms located in Slaskie appear to fund a lower share of their assets with debt financing, holding significantly lower short-term debt.

A more detailed analysis of firms' financial choices, by size, is reported in Table 9. We observe that the subset of foreign firms which seem to rely more on intermediated (long-term) financing are specifically SMEs. Governmental firms, on the other hand, seem to always choose lower debt ratios, regardless of their specific size. We also observe that the relevance of the financial determinants we have examined proves to be more unambiguous in the case of SMEs' financial choices. Neither size, age, growth opportunities, or collateral value have any explanatory power for the leverage ratios chosen by large firms within the sample. This finding is not surprising if we stay with our interpretation that banks choose to channel their lending towards high growth firms or/and firms which can offer good collateral; conditions that are likely to be more crucial when referring to the credit supply of SMEs. Large firms, on the other hand, seem to have leverage choices (possibilities) more connected to ownership structure. ${ }^{16}$

By introducing size, region and ownership dummies into the analysis (Table 8), we observed that SMEs maintained significantly higher short-term debt (both with banks and with suppliers) than large firms. However, once we run the analysis by sectors, we actually find that the previous pattern is only evident within the manufacturing sector. Small and medium manufacturing firms hold debt to assets ratios which are significantly above those of large firms; this higher leverage being mostly concentrated on the short-run (See Table 10).

Also, Table 10 demonstrates that our previous result showing that foreign firms maintained higher long-term debt to assets ratios holds true primarily for the Agricultural sector. Even though Manufacturing and Services foreign firms also show long-term debt to assets ratios that are higher than those corresponding to private domestic firms within those respective sectors, this difference is economically moderate in relative terms; foreign Agricultural firms, however, present ratios that are substantially above those we encounter in Agricultural companies owned by private domestic investors. Finally, we observe that foreign firms in all sectors tend to hold lower trade credit financing.

\footnotetext{
${ }^{15}$ Results are available from the authors.

${ }^{16}$ This result may also be connected to the lower representation of large firms within the sample.
} 
Finally, by looking at by-sector regressions we observe that size and tangibility are better predictors of firms' financial structures when we refer to either manufacturing or services firms. In these cases, both larger and more tangible asset structures are positively correlated to the use of debt financing. Neither of these appears to be relevant, however, in the case of agricultural firms.

The last topic we would like to analyze is related to governance issues. The sample shows a high degree of ownership concentration ${ }^{17}$. This may imply that agency problems are low (no minority shareholders to worry about) or that agency problems are high, interpreting this concentration as a response to a weak institutional environment (if minority shareholders are not able to enforce property rights, shareholders may prefer to enter with highly concentrated ownership). It is important to note that this concern may not be extended to firms that have been privatized under the National Investment Funds (NIF) program, in which case it was the law that led to high ownership concentration. ${ }^{18}$

To analyze the impact of corporate governance on firms' capital structure decisions, we incorporate two alternative subsets of dummy variables in each of our regressions: the first set of dummies identifies firms with majority holding (greater than $50 \%$ ), owned by either a foreign or a private domestic investor. We report these regressions in Table 11.

The only substantial result we obtain here indicates that firms held by majority domestic investors maintain significantly lower leverage ratios than other firms (either with a majority foreign or without majority owner). This result is not surprising given that the presence of a large shareholder reduces agency costs between managers and shareholders and consequently, the use of debt financing as a tool for limiting managerial discretion and its corresponding costs becomes less crucial. The fact that this is found only for the case of domestic majority owners may indicate that foreign investors take different paths when dealing with this issue.

The second set of dummies identifies majorities held by the state, an individual or an industrial. We observe that when the majority owner is the state, firms tend to choose higher leverage ratios (both total and short-term debt) and lower use of commercial credit (relative to firms without a majority owner). One reason for this could be that since the state is the ultimate owner, the threat of bankruptcy is of lesser importance: state-owned firms can be bailed out by the government, which implies a credit guarantee.

We can summarize our findings related to firms' financing patterns by identifying what we believe to be the two major forces at work: on one side is the "supply" of financing and on the other side is the "demand" for external funds. In the first case, supply seems to be predominantly oriented towards firms that can prove profitability, growth, and

\footnotetext{
${ }^{17}$ For the subset of firms with non-missing ownership information, more than $65 \%$ have one single owner, either domestic or foreigner.

${ }^{18}$ National Investment Funds program, known also as the Mass Privatization Program, is carried out on the basis of the Law on National Investment Funds of April 30th, 1993. The goal to transfer part of the selected state property to all entitled citizens through the emission of holding share certificates, later converted into the shares of national investment funds. $60 \%$ of each company's shares were distributed among 15 funds. In order to avoid excessive dispersion, $33 \%$ of each company's shares were vested in 1 of the 15 funds and the other $27 \%$ evenly distributed among the remaining 14 funds
} 
a supporting asset structure. Demand, in the second case, appears to be mostly connected to asymmetric information problems, which lead firms to take financing decisions based on a hierarchical structure that gives priority to the use of internally generated funds and postpones equity issues until debt capacity has been exhausted. As a result, we find that larger, more tangible, growing, profitable young firms to be the ones making relatively heavier use of debt in their financial structures.

\section{Section 5: Conclusions}

This study shows that Polish firms in the aggregate experience high growth, but average weak performance and low employment generation. In addition, firms seem to maintain low leverage ratios, with a small share of intermediated financing in general, and less long-term financing in particular.

We find that SMEs are generally younger and less prone to create job opportunities, in the aggregate. However, newly created SMEs are found to be the most active employment generators. That is, although SMEs do not appear to have been dynamic employers in the past, they have proved to be intense promoters of job opportunities in recent years. Small firms generally receive a substantial part of their financing structure from suppliers and provide significant financing to their customers. They are found to be somewhat financially healthier, with a lower percentage of firms with coverage ratios indicating the risk of default.

Regarding the consequences of varied ownership structures, we find that state owned enterprises (SOEs) are the oldest within the sample; they are significantly larger and employ a much larger work force. Nevertheless, SOEs exhibit the lowest growth rates among all firms we consider, experiencing negative employment growth rates. This implies that even though these firms might have been the big employers in prior years, their importance has diminished over time. SOEs also have the lowest leverage and profitability ratios among all ownership categories (at the year 2002). Foreign and private domestic firms, on the contrary, exhibit positive profitability measures for the same period. Domestic private firms are generally younger and smaller, and present somewhat higher leverage and profitability ratios. Nevertheless, we find all firm categories facing more compromised financial conditions and lower profitability ratios over time.

Finally, we test some key theories of capital structure. We believe these results to be particularly interesting, since there are only few studies that cover such a large sample of SMEs, located in any country other than the US. We observe that larger firms generally exhibit greater leverage ratios; however, opposite to what is suggested by the agency view, older firms actually present lower leverage figures. This could be a special feature of transition economies, where age is not precisely a valid proxy for good reputation. We also find leverage ratios to be positively related to tangibility, growth and industry concentration. One reason behind these relations is likely to be connected to the supply side: after liberalization, potential financiers choose to direct their credit towards younger, healthier and growing firms, so that they can share in their good future. Also, they are prone to favor firms with a higher collateral base, to ensure recovery. On the demand side, firms appear to be mostly influenced by asymmetric information problems, which lead 
them to take financing decisions based on a hierarchical structure, giving priority to the use of internally generated funds, and postponing equity issues until debt capacity has been exhausted. This contributes to our main empirical finding that larger, younger, growing, more profitable and tangible firms are relatively heavier users of debt in their financial structures. 


\section{References}

Acs, Z. J. and D. B. Audretsch, 1991, R \& D, Firm Size and Innovative Activity, in Acs, Z. J. and D. B. Audretsch (eds), Innovation and Technological Change, Harvester Wheatsheaf, London.

Berger, A and G. Udell, 1995, Relationship Lending and Lines of Credit in Small Fir m Finance, Journal of Business, 351-81.

Bilsen, V. and J. Konings, 1998, Job Creation, Job Destruction and Growth of Newly Established, Privatized and State-owned Enterprises in Transition Economies: Survey Evidence from Bulgaria, Hungary and Romania, Journal of Comparative 26, 429-445.

Booth L., Aivazian V., Demirguc-Kunt A. and Maksimovic V, 2001, "Capital Structures in Developing Countries", The Journal of Finance, LVI(1).

Broadman H. and Recanatini F., 2001, Is Russia Restructuring? New Evidence on Job Creation and Destruction, World Bank Policy Research Working Paper 2641.

C. G. and R. Chaganti, 1998, Businesses without Glamour? An Analysis of Resources on Performance by Size and Age in Small Service and Retail Firms, Journal of Business Venturing 14, 233-257.

Budina N., Garretsen H. and Jong E., 2000, Liquidity Constraints and Investment in Transition Economies: The Case of Bulgaria, World Bank Policy Research Working Paper 2278.

Carare, O. and Perotti, E. C., 1997, The Evolution of Bank Credit Quality in Transition: Theory and Evidence from Romania, Discussion Paper 97/02, CERT.

Colombo, E, 2001, Determinants of Corporate Capital Structure: Evidence from Hungarian Firms, Applied Economics 33, 1689-1701.

Chaves R., Sanchez S., Schor S. and Tesliuc E., 2001, Financial Markets, Credit Constraints, and Investment in Rural Romania, World Bank Technical Paper N. 499.

Cornelli, F., Portes, R. and Scaffer, M.E., 1996, The Capital Structure of Firms in Central and Eastern Europe, Centre for Economic Policy Research Discussion Paper No. 1392.

Cressy R. and Olofsson C., 1997, "The Financial Constraints for Swedish SMEs: Survey and Research Agenda", Small Business Economics

Demirguc-Kunt, A. and Maksimovic V., 1998, “Law, Finance, and Firm Growth”, Journal of Finance 53, 2107-2139. 
Demirguc-Kunt, A., and V. Maksimovic, 2002, " Funding Growth in Bank-based and Market-Based Financial Systems: Evidence from Firm-Level Data", Journal of Financial Economics, 337-363.

Dević A. and Krstić B. , 2001, "Comparative analysis of the Capital Structure determinants in Polish and Hungarian Enterprises, Empirical Study”, . Facta Universitatis, Economics and Organization Series, Vol. 1, No 9, 2001, pp. 85 - 100

DeAngelo, H., and Masulis R.W, 1980, “Optimal Capital Structure under Corporate and Personal Taxation”, Journal of Financial Economics 8, pp. 3-29.

Diamond R., 1989, "Reputation Acquisition in Debt Markets", Journal of Political Economy, Vol 97

Egerer R., 1995, “Capital Markets, Financial Intermediaries, and Corporate Governance : an Empirical Assessment of the Top Ten Voucher Funds in the Czech Republic", World Bank Policy Research Working Paper, WPS1555

Estrin S., Konings J., Zolkiewski Z., Angelucci M., 2001, "The Effect of Ownership and Competitive Pressure on Firm Performance in Transition Countries. Micro Evidence from Bulgaria, Romania and Poland”, LICOS Katholieke Universiteit Leuven

Fama, E. F., and French K. , 2002, “Testing Tradeoff and Pecking Order Predictions about

Dividends and Debt”, Review of Financial Studies 15, 1-33.

Frye, T. and A. Shleifer, 1997, The Invisible Hand and the Grabbing Hand, American Economic Review Papers and Proceedings 87, 354-358.

Gros D. and Suhrcke M, 2000, Ten Years After: What is Special About Transition Countries?, European Bank Working Paper N. 56.

Grossman S. and Hart O., (1982) "Corporate Financial Structure and Managerial Incentives," in J. J.McCall, ed., The Economics of Information and Uncertainty (Chicago, IL: University of Chicago Press, 1982

Hamilton R., Fox M (1998)., "The Financing Preferences of Small Firm Owners", International Journal of Entrepreneurial Behaviour and Research, Vol 4, No 3, November 1998, pp. 239-248(10)

Harper J. and Krehbiel T., 1999, "An Empirical Investigation of the Relationship between Ownership Structure and Operating Performance of Newly Privatized Czech Firms", Advances in Financial Economics, Vol 4..Standford, 19-101

Harris M. and Raviv A., 1991, "The Theory of Capital Structure”, The Journal of Finance, 46(1):297-355. 
Havas, A, 2002, Does Innovation Policy Matter in a Transition Country? The Case of Hungary, Journal of International Relationships and Development Policy 4, 380-402.

Jensen M., 1986, "Agency Costs of Free Cash Flow, Corporate Finance and Takeovers", The American Economic Review, 76(2), 323-329.

Johnson, Simon, John McMillan and Christopher Woodruff, 2002, Property Rights and Finance, The World Bank, Washington D.C.

Kim W.S. and Sorensen E. (1986), "Evidence on the impact of the Agency Cost of Debt on Corporate Debt Policy" The Journal of Financial and Quantitative Analysis, 21(2).

Klapper, F. Sarria-Allende, V. and V. Sulla, 2003, Small and Medium-size Enterprise Financing in Transition Easter Europe, World Bank Policy Research Paper 2933.

Konings, J., Vandenbussche, H and M. Rizov, 2003, Investment and Financial Constraints in Transition Economies: Micro Evidence from Poland, the Czech Republic, Bulgaria and Romania, Economic Letters 78, 253-258.

La Porta, R., Lopez-de-Silanes F., Shleifer A. and Vishny R. W., 1998, “Law

and Finance”, Journal of Political Economy 106, 1113-1155.

Levitsky J., 1996, “Small Business in Transition Economies”, London: ITDG Publications

Lloyd-Reason, L. Muller, K. and S. Wall, 2002, Innovation and Education Policy in SMEs: A Czech Perspective, Education + Training 44, 378-387.

Miller M., 1977, “Debt and Taxes”, Journal of Finance 32, 261-275

Modigliani-Miller, 1958 "The Cost of Capital, Corporation Finance and the Theory of Investment", American Economic Review

Modigliani-Miller, 1965, "The Cost of Capital, Corporation Finance and the Theory of Investment: Reply", The American Economic Review, June, 55(3).

Modigliani F and Miller M.,1963, "Corporate Income Taxes and the Cost of Capital: a Correction", American Economic Review, 53, 433-443

Myers S. and Majluf N., 1984, "Corporate Financing and Investment Decisions When Firms Have Information that Investors do not Have" Journal of Financial Economics 13, $187-224$

OECD (1996).

Peel, M. J. and N. Wilfson, 1996, Working Capital and Financial Management Practices in the Small Firm Sector, International Small Business Journal 14, 52-68. 
Pissarides F., 1999, “Is Lack of Funds the Main Obstacle to Growth? EBRD's Experience with Small and Medium Business in Central and Eastern Europe", Journal of Business Venturing 14, 519-539

Rajan R. and Zingales L., 1995, "What do we know about Capital Structure? Evidence from International Data", The Journal of Finance 50(5):1421-1460.

Scherr, 1990, Financing the Small Firm Startup: Determinants of Debt Use, Proceedings Second Annual Small Firm Finance Research Symposium.

Shleifer, A., 1997, Government in Transition, Eurpoean Economic Review 41, 385-410

Weller, C., 1999, The Finance-Investment Link in a Transition Economy: Evidence for Poland from Panel Data, Centre for European Integration Studies Working Paper B4.Working Paper Series No. W8641

Titman S. and Wessels R., 1998, "The Determinants of Capital Structure Choice", The Journal of Finance, 43(1):1-19

Titman S.(2001), “ The Modigliani and Miller Theorem and Market Efficiency” NBER

Welch I., 2004, "Capital Structure and Stock Returns”, Journal of Political Economy 112-1, 106-1311

World Bank Report, 2002, Transition, The First Ten Years, Analysis and Lessons for Eastern Europe and the Former Soviet Union. 
Figure 1

Evolution by Sector
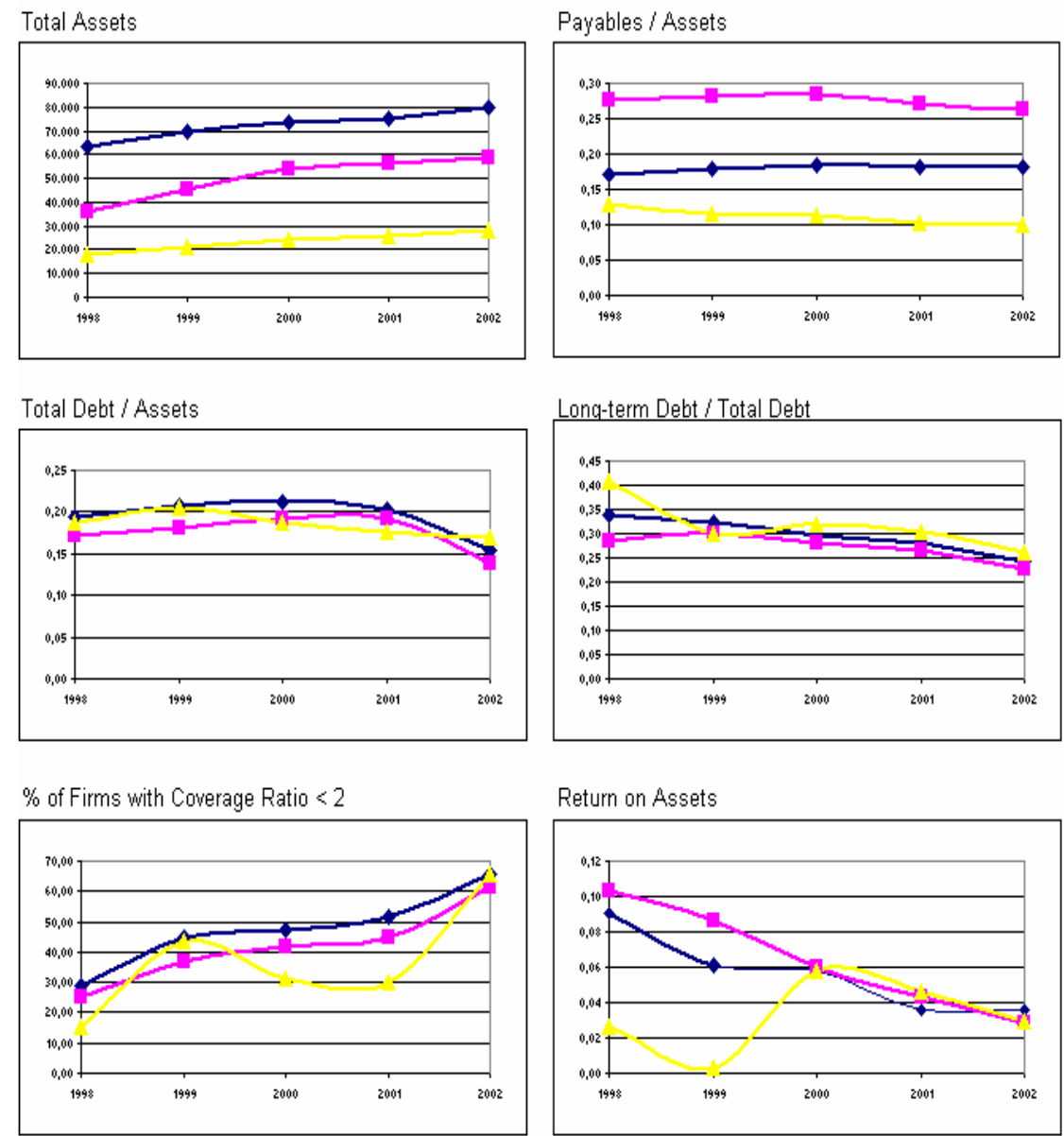

$\rightarrow-$ Marnfacturing $\rightarrow-$ Services

Agriculture

\section{Evolution by Age}
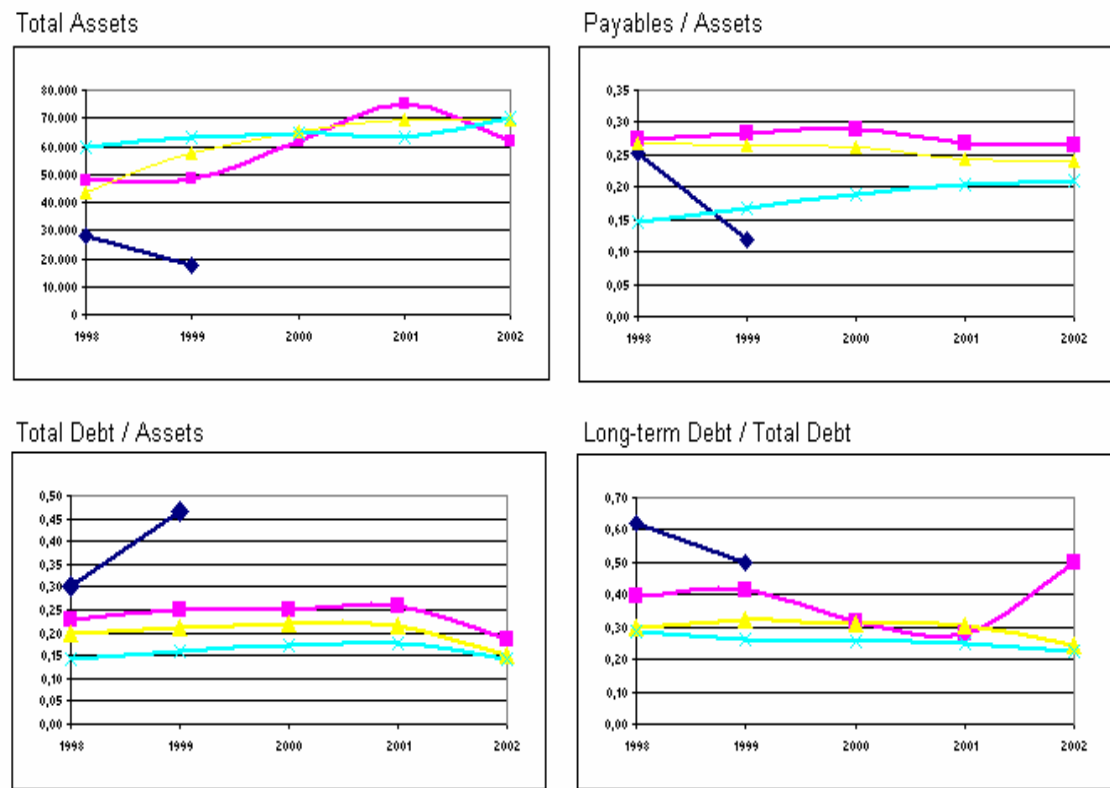

Long-term Debt / Total Debt
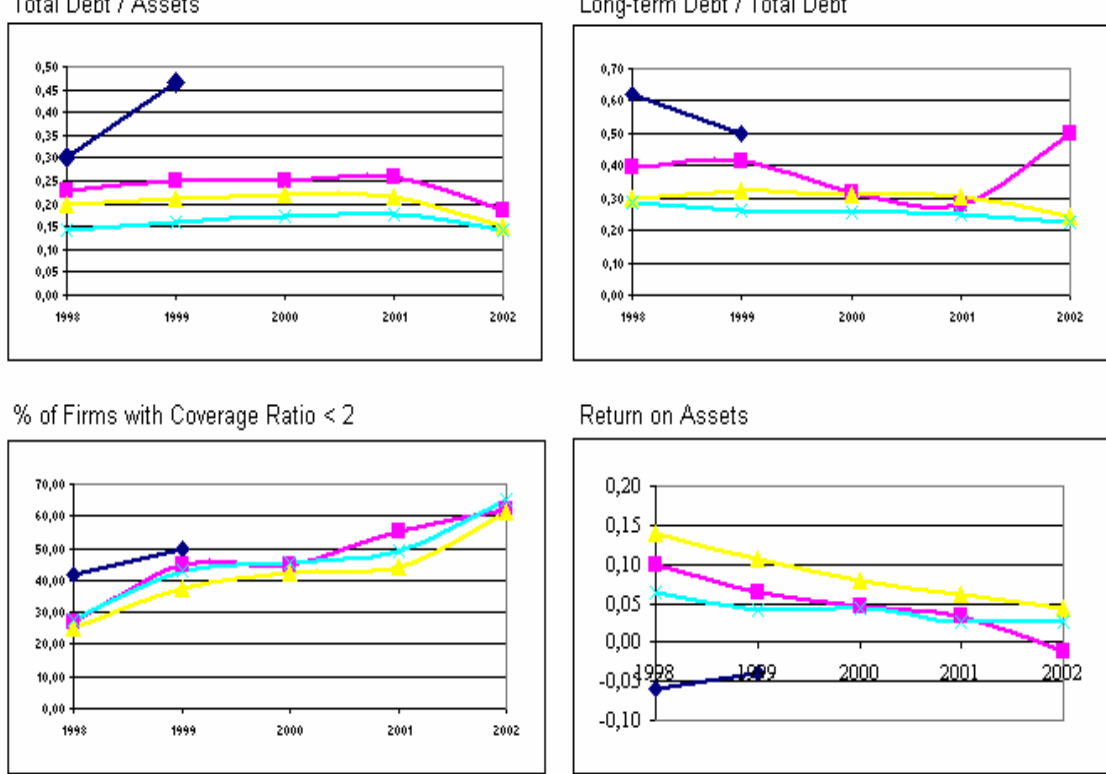

Return on Assets

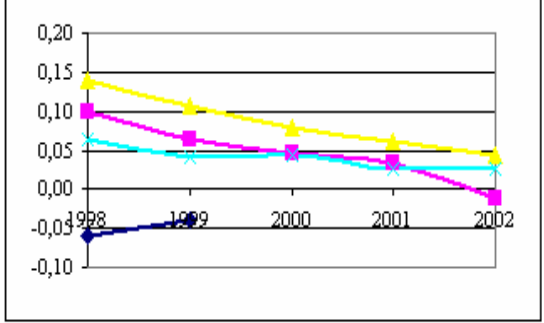

$\rightarrow-0-1 \rightarrow-2-5 \quad-6-10 \rightarrow \leftarrow \rightarrow 10$ 


\section{Table 1 Panel A: Distribution of Firms in the Study (Year 2002)}

This sample includes all nonfinancial, publicly traded, private and government owned firms. This table presents year 2002 distribution of firms in the sample across size categories. Size is determined using the official EU definitions; Micro firms are those with total assets or sales less than $€ 2$ million; Small firms are those with total assets or sales less than $€$ 10 million, Medium size firms with either total assets less than $€ 43$ million or sales less than $€ 50$ million and Large firms with total assets greater than $€ 43$ million or sales greater than $€ 50$ million. Age is the number of years since incorporation. Industry Type "Others" includes fishing and forestry

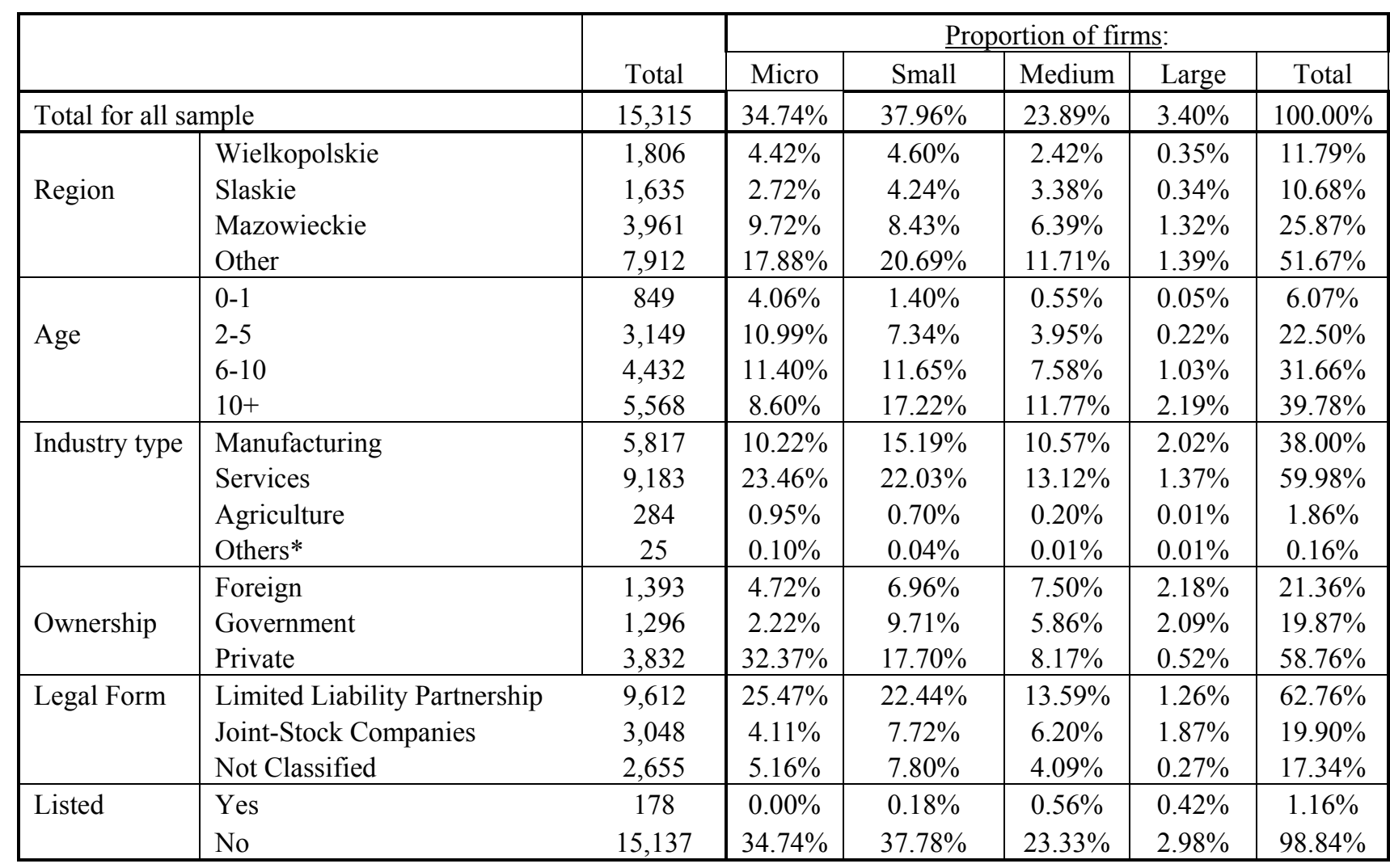




\section{Table 1 Panel B: Summary Statistics by Ownership Structure (Year 2002)}

This table presents the ownership distribution of firms across size and age. Total $\mathrm{N}^{\circ}$ of Firms is described as the Total $\mathrm{N}^{\circ}$ of firms in the corresponding categories; Percentage of firms with non-missing information $=\left(\mathrm{N}^{\circ}\right.$. Non-missing Firms/Total Number of Firms). Wholly-Owned foreign (domestic) is defined as $100 \%$ owned by one foreign (or domestic) industrial shareholder. Size is determined according to EU official definitions. All financial ratios are corrected for outliers at the $1 \%$ or $5 \%$ critical levels.

\begin{tabular}{|c|c|c|c|c|c|c|c|c|c|c|c|c|c|c|c|}
\hline \multirow[b]{3}{*}{$\begin{array}{l}\% \text { of total firms with nonmissing } \\
\text { obs* }\end{array}$} & \multirow[t]{2}{*}{$\begin{array}{c}\text { All } \\
\text { Firms } \\
\end{array}$} & \multicolumn{4}{|c|}{ By Size* } & \multicolumn{4}{|c|}{ By Age } & \multicolumn{3}{|c|}{ By Sector } & \multicolumn{3}{|c|}{ By Ownership } \\
\hline & & Micro & Small & Medium & Large & $\begin{array}{c}\% \\
\text { Age } 0-1 \\
\end{array}$ & $\begin{array}{c}\% \\
\text { Age 2-5 }\end{array}$ & $\begin{array}{c}\% \\
\text { Age } 6-10 \\
\end{array}$ & $\begin{array}{c}\% \\
\text { Age }>10\end{array}$ & $\%$ Industry & $\%$ Services & \%Agriculture & Foreign & Government & Private \\
\hline & $27 \%$ & $17.51 \%$ & $28.05 \%$ & $35.04 \%$ & $52.98 \%$ & $17.55 \%$ & $27.05 \%$ & $30.89 \%$ & $25.35 \%$ & $31.01 \%$ & $24.12 \%$ & $33.45 \%$ & $61.95 \%$ & $85.26 \%$ & $22.12 \%$ \\
\hline Total \# firms & 15,315 & 5,321 & 5,814 & 3,659 & 521 & 849 & 3,149 & 4,432 & 5,568 & 5,817 & 9,183 & 284 & 1,393 & 1,296 & 3,832 \\
\hline \multicolumn{16}{|l|}{ \% of Firms: } \\
\hline With 1 shareholder & 56.23 & 49.39 & 61.06 & 59.09 & 52.02 & 44.99 & 52.37 & 53.36 & 62.43 & 56.39 & 56.03 & 59.15 & 20.46 & 70.45 & 33.79 \\
\hline With 2-5 shareholders & 42.92 & 49.86 & 38.20 & 40.15 & 44.15 & 54.53 & 46.78 & 45.96 & 36.48 & 42.63 & 43.16 & 40.85 & 78.89 & 29.32 & 65.92 \\
\hline With more than 5 shareholders & 0.86 & 0.75 & 0.74 & 0.77 & 3.84 & 0.47 & 0.86 & 0.68 & 1.10 & 0.98 & 0.79 & 0.00 & 0.65 & 0.23 & 0.29 \\
\hline $\begin{array}{l}\text { Wholly-owned foreign } \\
\text { subsidiary** }\end{array}$ & 11.21 & 6.76 & 9.26 & 15.21 & 19.20 & 6.71 & 11.85 & 15.70 & 6.44 & 11.09 & 11.73 & 1.05 & 53.53 & - & - \\
\hline Wholly-owned domestic subsidiary & 1.55 & 1.61 & 0.86 & 2.57 & 0.72 & 1.34 & 2.00 & 1.68 & 0.64 & 1.33 & 1.81 & 0.00 & - & - & 7.55 \\
\hline$>50 \% 1$ domestic shareholder & 46.71 & 48.93 & 50.71 & 41.03 & 42.03 & 44.30 & 32.98 & 36.60 & 66.57 & 46.67 & 45.67 & 69.47 & - & 97.92 & 99.41 \\
\hline$>50 \% 1$ foreign shareholder & 20.58 & 15.99 & 17.41 & 25.66 & 31.16 & 21.48 & 22.07 & 27.98 & 11.54 & 20.79 & 21.12 & 4.21 & 96.18 & 1.63 & - \\
\hline$>50 \% 1$ state shareholder & 26.69 & 11.48 & 34.40 & 25.20 & 39.49 & 18.79 & 9.74 & 18.63 & 46.18 & 29.55 & 23.01 & 54.74 & - & 99.55 & - \\
\hline$>50 \% 1$ individual shareholder & 25.77 & 44.31 & 22.07 & 20.67 & 8.70 & 35.57 & 29.34 & 26.59 & 22.88 & 23.34 & 28.16 & 17.89 & 33.14 & - & 91.51 \\
\hline$>50 \% 1$ industrial shareholder & 13.64 & 8.37 & 10.36 & 19.27 & 24.64 & 8.72 & 14.32 & 18.04 & 8.43 & 13.69 & 14.12 & 1.05 & 57.47 & - & 7.78 \\
\hline $\begin{array}{l}\text { Shareholding of largest shareholder } \\
(\%) \\
\text { Cummulative shareholding of top } 3 \\
\text { shareholders (\%) } \\
\text { Cummulative shareholding of top } 5 \\
\text { shareholders }(\%)\end{array}$ & $\begin{array}{l}69.57 \\
82.52 \\
83.24\end{array}$ & $\begin{array}{l}60.97 \\
83.95 \\
87.61\end{array}$ & $\begin{array}{l}72.75 \\
83.22 \\
83.57\end{array}$ & $\begin{array}{l}78.79 \\
77.74 \\
72.21\end{array}$ & $\begin{array}{l}79.98 \\
64.18 \\
62.64\end{array}$ & $\begin{array}{l}61.22 \\
87.29 \\
91.90\end{array}$ & $\begin{array}{l}85.56 \\
89.34\end{array}$ & $\begin{array}{l}71.67 \\
82.70 \\
84.85\end{array}$ & 78.43 & 81.48 & 83.25 & $\begin{array}{l}78.93 \\
86.09\end{array}$ & $\begin{array}{r}83.63 \\
87.08 \\
100.00\end{array}$ & $\begin{array}{l}93.85 \\
77.21 \\
81.56\end{array}$ & $\begin{array}{l}62.67 \\
86.91\end{array}$ \\
\hline
\end{tabular}




\section{Table 2: Summary Statistics (Year 2002)}

All financial ratios are corrected for outliers at the $1 \%$ or $5 \%$ critical levels

\begin{tabular}{|c|c|c|c|c|c|c|c|c|c|c|}
\hline Variables * & $\begin{array}{c}\text { Number of } \\
\text { Observations }\end{array}$ & Mean & $\begin{array}{l}\text { Standard } \\
\text { Deviation }\end{array}$ & Min & p5 & $\mathrm{p} 25$ & Median & p75 & p95 & Max \\
\hline Age & 13,998 & 16.60 & 26.51 & 0.00 & 1.00 & 5.00 & 9.00 & 13.00 & 57.00 & 761.00 \\
\hline Total Assets (PLN) & 15,315 & 53,537 & 476,805 & 1 & 303 & 1,889 & 8,704 & 24,872 & 155,232 & $36,900,000$ \\
\hline 1-Yr Asset growth & 12,836 & 0.17 & 0.58 & -1.00 & -0.35 & -0.07 & 0.05 & 0.24 & 0.99 & 3.74 \\
\hline Total Sales (PLN) & 15,179 & 65,055 & 390,946 & 1 & 892 & 3,920 & 13,854 & 37,939 & 203,651 & $26,300,000$ \\
\hline 1-Yr Sales growth & 12,629 & 0.24 & 1.08 & -1.00 & -0.45 & -0.11 & 0.03 & 0.20 & 1.37 & 7.33 \\
\hline Employment & 11,944 & 239 & 1,440 & 1 & 5 & 26 & 82 & 200 & 800 & 101,985 \\
\hline 1-Year Employment Growth & 9,847 & 0.00 & 0.22 & -1.00 & -0.28 & -0.06 & 0.00 & 0.00 & 0.33 & 1.13 \\
\hline Debt to total assets & 15,051 & 0.11 & 0.17 & 0.00 & 0.00 & 0.00 & 0.02 & 0.16 & 0.46 & 0.94 \\
\hline Payables to total assets & 15,185 & 0.27 & 0.27 & 0.00 & 0.00 & 0.06 & 0.19 & 0.42 & 0.84 & 1.11 \\
\hline Liabilities to total assets & 12,942 & 0.64 & 0.38 & 0.03 & 0.11 & 0.37 & 0.61 & 0.84 & 1.29 & 2.04 \\
\hline Long-term debt to total assets & 15,051 & 0.04 & 0.11 & 0.00 & 0.00 & 0.00 & 0.00 & 0.01 & 0.24 & 0.72 \\
\hline Long-term debt to total debt & 8,248 & 0.28 & 0.36 & 0.00 & 0.00 & 0.00 & 0.02 & 0.56 & 1.00 & 1.00 \\
\hline Current Ratio & 15,263 & 1.72 & 2.11 & 0.00 & 0.32 & 0.81 & 1.13 & 1.74 & 4.92 & 14.55 \\
\hline $\begin{array}{l}\text { Percentage of firms with interest coverage less } \\
\text { than } 2\end{array}$ & 15,315 & 52.20 & 49.95 & - & - & - & - & - & - & \\
\hline Asset Tangiblility & 14,922 & 0.36 & 0.27 & 0.00 & 0.01 & 0.11 & 0.32 & 0.56 & 0.84 & 1.00 \\
\hline Receivables to total assets & 15,309 & 0.32 & 0.23 & 0.00 & 0.03 & 0.13 & 0.27 & 0.47 & 0.77 & 0.90 \\
\hline Earnings/Sales & 15,156 & 0.00 & 0.20 & -1.27 & -0.25 & -0.01 & 0.02 & 0.06 & 0.19 & 0.41 \\
\hline Return on Assets & 15,283 & 0.05 & 0.21 & -0.76 & -0.29 & -0.01 & 0.05 & 0.13 & 0.37 & 0.68 \\
\hline
\end{tabular}




\section{Table 3 Panel A: Mean Summary Statistics by Size and Age (Year 2002)}

This table reports mean figures for year 2002 across size and age. Size is determined using the official EU definitions; Micro firms are those with total assets or sales less than $€ 2$ million; Small firms are those with total assets or sales less than $€ 10$ million, Medium size firms with either total assets less than $€ 43$ million or sales less than $€ 50$ million and Large firms with total assets greater than $€ 43$ million or sales greater than $€ 50$ million. All financial ratios are corrected for outliers at the $1 \%$ or $5 \%$ critical levels. Significance at

$1 \%, 5 \%$ and $10 \%$ levels is represented as $* * *, * *, *$ respectively; NS means differences are not significant.

\begin{tabular}{|c|c|c|c|c|c|c|c|c|c|c|c|}
\hline \multirow{4}{*}{$\begin{array}{l}\% \text { of total firms with nonmissing obs } \\
\text { \# firms }\end{array}$} & \multicolumn{4}{|c|}{ Size } & \multirow[b]{2}{*}{$\begin{array}{c}\text { t-test } \\
\text { Small vs } \\
\text { Large } \\
\end{array}$} & \multicolumn{6}{|c|}{ Age } \\
\hline & Micro & Small & Medium & Large & & $\begin{array}{c}\text { t-test } \\
\text { Micro vs } \\
\text { Large } \\
\end{array}$ & $\begin{array}{c}\% \text { Age } 0- \\
1\end{array}$ & $\begin{array}{l}\% \text { Age } 2- \\
5\end{array}$ & $\begin{array}{c}\% \text { Age } 6- \\
10\end{array}$ & $\begin{array}{l}\% \text { Age } \\
>10\end{array}$ & $\begin{array}{l}\text { t-test } \\
\text { New vs } \\
>10\end{array}$ \\
\hline & $34.73 \%$ & $37.98 \%$ & $23.88 \%$ & $3.40 \%$ & & & $6.06 \%$ & $22.50 \%$ & $31.66 \%$ & $39.78 \%$ & \\
\hline & 5,321 & 5,814 & 3,659 & 521 & & & 849 & 3,149 & 4,432 & 5,568 & \\
\hline Age & 8.36 & 18.58 & 23.03 & 34.01 & $* * *$ & $* * *$ & 0.83 & 3.32 & 8.19 & 33.20 & $* * *$ \\
\hline Total Assets (PLN) & 2,265 & 15,816 & 62,908 & 932,300 & $* * *$ & $* * *$ & 12,499 & 24,741 & 44,616 & 85,304 & $* * *$ \\
\hline 1-Yr Asset growth & 0.19 & 0.15 & 0.19 & 0.17 & NS & NS & 0.62 & 0.29 & 0.13 & 0.11 & $* * *$ \\
\hline Total Sales (PLN) & 3,099 & 18,790 & 93,022 & $1,008,975$ & $* * *$ & $* * *$ & 17,206 & 33,863 & 57,264 & 97,184 & $* * *$ \\
\hline 1-Yr Sales growth & 0.38 & 0.16 & 0.22 & 0.25 & $* *$ & $*$ & 2.33 & 0.47 & 0.15 & 0.04 & $* * *$ \\
\hline Employment & 32 & 141 & 307 & 2,132 & $* * *$ & $* * *$ & 98 & 119 & 166 & 344 & $* *$ \\
\hline 1-Year Employment Growth & -0.01 & -0.01 & 0.02 & 0.03 & $* * *$ & $* * *$ & 0.27 & 0.07 & 0.02 & -0.03 & $* * *$ \\
\hline Debt to total assets & 0.09 & 0.11 & 0.13 & 0.12 & NS & $* * *$ & 0.09 & 0.11 & 0.11 & 0.10 & $* * *$ \\
\hline Payables to total assets & 0.31 & 0.26 & 0.27 & 0.18 & $* * *$ & $* * *$ & 0.36 & 0.34 & 0.28 & 0.22 & $* * *$ \\
\hline Liabilities to total assets & 0.67 & 0.61 & 0.64 & 0.60 & NS & $* * *$ & 0.67 & 0.72 & 0.63 & 0.59 & $* * *$ \\
\hline Long-term debt to total assets & 0.06 & 0.07 & 0.06 & 0.06 & NS & $* *$ & 0.05 & 0.09 & 0.06 & 0.05 & NS \\
\hline Long-term debt to total debt & 0.31 & 0.29 & 0.26 & 0.30 & NS & NS & 0.29 & 0.35 & 0.29 & 0.25 & $*$ \\
\hline Current Ratio & 2.12 & 1.59 & 1.41 & 1.32 & $* * *$ & $* * *$ & 1.95 & 1.77 & 1.82 & 1.60 & $* * *$ \\
\hline $\begin{array}{l}\text { Percentage of firms with interest } \\
\text { coverage }<2\end{array}$ & 37.04 & 56.24 & 64.96 & 72.36 & $* * *$ & $* * *$ & 34.75 & 49.06 & 50.32 & 57.70 & $* * *$ \\
\hline Asset Tangiblility & 0.29 & 0.39 & 0.39 & 0.46 & $* * *$ & $* * *$ & 0.26 & 0.32 & 0.34 & 0.40 & $* * *$ \\
\hline Receivables to total assets & 0.36 & 0.30 & 0.31 & 0.24 & $* * *$ & $* * *$ & 0.39 & 0.35 & 0.33 & 0.28 & $* * *$ \\
\hline Earnings/Sales & -0.01 & 0.01 & 0.01 & 0.02 & NS & $* * *$ & -0.01 & -0.01 & 0.02 & 0.00 & $* *$ \\
\hline Return on Assets & 0.04 & 0.05 & 0.05 & 0.04 & $*$ & NS & 0.07 & 0.04 & 0.06 & 0.04 & $* * *$ \\
\hline
\end{tabular}




\section{Table 3 Panel B: Mean Summary Statistics by Ownership Structure and Legal Form (Year 2002)}

This table reports summary mean statistics for year 2002 according to ownership structure and legal form. LLP stands for Limited Liability Partnership. All financial ratios are corrected for outliers at the $1 \%$ or $5 \%$ critical levels. Significance at $1 \%, 5 \%$ and $10 \%$ levels is represented as $* * *, * * *$ respectively ; NS means differences are not significant

\begin{tabular}{|c|c|c|c|c|c|c|c|c|c|}
\hline & \multicolumn{6}{|c|}{ Ownership } & \multicolumn{3}{|c|}{ Legal Form } \\
\hline \multirow[b]{2}{*}{$\begin{array}{l}\% \text { of total firms with nonmissing obs } \\
\text { \# firms }\end{array}$} & Foreign & Government & Private & $\begin{array}{c}\text { t-test } \\
\text { Foreign vs } \\
\text { Government } \\
\end{array}$ & $\begin{array}{c}\text { t-test } \\
\text { Foreign } \\
\text { vs Private } \\
\end{array}$ & $\begin{array}{c}\text { t-test } \\
\text { Private vs } \\
\text { Government } \\
\end{array}$ & LLP $^{\mathrm{a}}$ & $\begin{array}{l}\text { Joint-Stock } \\
\text { Company }\end{array}$ & $\begin{array}{c}\text { t-test } \\
\text { LLP vs } \\
\text { Joint-Stock }\end{array}$ \\
\hline & $\begin{array}{l}21.36 \% \\
1,393\end{array}$ & $\begin{array}{l}19.90 \% \\
1,296\end{array}$ & $\begin{array}{l}58.75 \% \\
3,832\end{array}$ & & & & $\begin{array}{l}62.78 \% \\
9,614\end{array}$ & $\begin{array}{l}19.97 \% \\
3,058\end{array}$ & \\
\hline Age & 12.14 & 33.63 & 9.40 & $* * *$ & $* * *$ & $* * *$ & 9.61 & 32.47 & $* * *$ \\
\hline Total Assets (PLN) & 120,882 & 176,509 & 14,781 & NS & $* * *$ & $* * *$ & 28,785 & 144,918 & $* * *$ \\
\hline 1-Yr Asset growth & 0.22 & 0.14 & 0.21 & $* * *$ & NS & $* * *$ & 0.19 & 0.14 & $* * *$ \\
\hline Total Sales (PLN) & 142,271 & 151,559 & 26,057 & NS & $* * *$ & $* * *$ & 42,364 & 153,249 & $* * *$ \\
\hline 1-Yr Sales growth & 0.31 & 0.12 & 0.38 & $* * *$ & NS & $* * *$ & 0.31 & 0.17 & $* * *$ \\
\hline Employment & 315 & 688 & 97 & $* * *$ & $* * *$ & $* * *$ & 140.25 & 416.02 & $* * *$ \\
\hline 1-Year Employment Growth & 0.03 & -0.04 & 0.04 & $* * *$ & NS & $* * *$ & 0.02 & -0.03 & $* * *$ \\
\hline Debt to total assets & 0.11 & 0.07 & 0.13 & $* * *$ & $* *$ & $* * *$ & 0.11 & 0.12 & $* *$ \\
\hline Payables to total assets & 0.31 & 0.13 & 0.33 & $* * *$ & $* * *$ & $* * *$ & 0.30 & 0.22 & $* * *$ \\
\hline Liabilities to total assets & 0.68 & 0.47 & 0.68 & $* * *$ & NS & $* * *$ & 0.66 & 0.64 & $* *$ \\
\hline Long-term debt to total assets & 0.07 & 0.04 & 0.07 & $* * *$ & NS & $* * *$ & 0.07 & 0.05 & $* * *$ \\
\hline Long-term debt to total debt & 0.27 & 0.31 & 0.30 & $* *$ & $*$ & NS & 0.30 & 0.23 & $* * *$ \\
\hline Current Ratio & 1.80 & 1.46 & 1.76 & $* * *$ & NS & $* * *$ & 1.78 & 1.64 & $* * *$ \\
\hline $\begin{array}{l}\text { Percentage of firms with interest } \\
\text { coverage }<2\end{array}$ & 56.64 & 64.74 & 43.06 & $* * *$ & $* * *$ & $* * *$ & 50.36 & 66.11 & $* * *$ \\
\hline Asset Tangiblility & 0.30 & 0.59 & 0.28 & $* * *$ & $* * *$ & $* * *$ & 0.32 & 0.38 & $* * *$ \\
\hline Receivables to total assets & 0.35 & 0.18 & 0.37 & $* * *$ & $* * *$ & $* * *$ & 0.35 & 0.28 & $* * *$ \\
\hline Earnings/Sales & 0.00 & -0.03 & 0.02 & $* * *$ & $* * *$ & $* * *$ & 0.01 & -0.04 & $* * *$ \\
\hline Return on Assets & 0.05 & -0.01 & 0.08 & $* * *$ & $* * *$ & $* * *$ & 0.06 & 0.00 & $* * *$ \\
\hline
\end{tabular}




\section{Table 3 Panel C: Mean Summary Statistics by Sector and Region (Year 2002)}

This table reports summary mean statistics for year 2002 according to sector classification and location. All financial ratios are corrected for outliers at the $1 \%$ or $5 \%$ critical levels; forestry and fishing are left out in the sector categories. Significance at $1 \%, 5 \%$ and $10 \%$ levels is represented as ***,**,* respectively; NS means difference is not significant

\begin{tabular}{|c|c|c|c|c|c|c|c|c|c|c|c|c|c|}
\hline & \multicolumn{6}{|c|}{ Sector } & \multicolumn{7}{|c|}{ Region } \\
\hline & $\begin{array}{c}\% \\
\text { Industry }\end{array}$ & $\begin{array}{c}\% \\
\text { Services }\end{array}$ & $\begin{array}{c}\% \\
\text { Ariculture }\end{array}$ & $\begin{array}{c}\mathrm{t} \text {-test } \\
\text { Industry } \\
\text { vs } \\
\text { Services } \\
\end{array}$ & $\begin{array}{c}\text { t-test } \\
\text { Industry } \\
\text { vs } \\
\text { Agriculture }\end{array}$ & $\begin{array}{c}\text { t-test } \\
\text { Services } \\
\text { vs } \\
\text { Agriculture } \\
\end{array}$ & Wielkopolskie & Slaskie & Mazowiecke & Others & $\begin{array}{c}\text { t-test } \\
\text { Wielkopolskie } \\
\text { vs } \\
\text { Slaskie } \\
\end{array}$ & $\begin{array}{c}\text { t-test } \\
\text { Wielkopolski } \\
\text { e vs } \\
\text { Mazoweicke } \\
\end{array}$ & $\begin{array}{c}\text { t-test } \\
\text { Slaskie } \\
\text { vs } \\
\text { Mazowiecke }\end{array}$ \\
\hline $\begin{array}{l}\% \text { of total firms with } \\
\text { nonmissing obs }\end{array}$ & $38.00 \%$ & $59.98 \%$ & $1.85 \%$ & & & & $11.79 \%$ & $10.68 \%$ & $25.87 \%$ & $51.67 \%$ & & & \\
\hline \# firms & 5,817 & 9,183 & 284 & & & & 1,806 & 1,635 & 3,961 & 7,912 & & & \\
\hline Age & 22.62 & 12.84 & 14.73 & $* * *$ & $* * *$ & NS & 16.52 & 20.99 & 12.48 & 17.84 & $* * *$ & $* * *$ & $* * *$ \\
\hline Total Assets (PLN) & 68,839 & 44,742 & 16,960 & $* * *$ & $* *$ & NS & 38,694 & 52,222 & 93,300 & 37,297 & NS & $* * *$ & $*$ \\
\hline 1-Yr Asset growth & 0.16 & 0.18 & 0.15 & $* *$ & NS & NS & 0.17 & 0.15 & 0.18 & 0.17 & NS & NS & $*$ \\
\hline Total Sales (PLN) & 81,481 & 55,965 & 14,353 & $* * *$ & $* *$ & $* *$ & 49,424 & 71,597 & 102,433 & 48,769 & $* * *$ & $* * *$ & $*$ \\
\hline 1-Yr Sales growth & 0.21 & 0.26 & 0.15 & $* *$ & NS & NS & 0.22 & 0.14 & 0.28 & 0.25 & $* *$ & $*$ & $* * *$ \\
\hline Employment & 290 & 202 & 90 & $* * *$ & $* * *$ & NS & 169 & 290 & 361 & 201 & $* * *$ & $* *$ & NS \\
\hline 1-Year Employment Growth & 0.00 & 0.00 & -0.04 & NS & $* *$ & $* *$ & 0.01 & -0.01 & 0.00 & 0.00 & $*$ & NS & $*$ \\
\hline Debt to total assets & 0.12 & 0.10 & 0.17 & $* * *$ & $* * *$ & $* * *$ & 0.11 & 0.09 & 0.09 & 0.12 & $* * *$ & $* * *$ & NS \\
\hline Payables to total assets & 0.23 & 0.31 & 0.16 & $* * *$ & $* * *$ & $* * *$ & 0.31 & 0.28 & 0.29 & 0.26 & $* * *$ & $* * *$ & NS \\
\hline Liabilities to total assets & 0.60 & 0.66 & 0.54 & $* * *$ & $* * *$ & $* * *$ & 0.65 & 0.64 & 0.68 & 0.61 & NS & $* *$ & $* *$ \\
\hline Long-term debt to total assets & 0.06 & 0.06 & 0.08 & NS & $* * *$ & $* *$ & 0.06 & 0.04 & 0.06 & 0.06 & $* * *$ & NS & $* * *$ \\
\hline Long-term debt to total debt & 0.29 & 0.28 & 0.32 & $*$ & NS & NS & 0.29 & 0.23 & 0.27 & 0.30 & $* * *$ & NS & $* * *$ \\
\hline Current Ratio & 1.67 & 1.73 & 2.31 & NS & $* * *$ & $* * *$ & 1.65 & 1.50 & 1.96 & 1.67 & $* *$ & $* * *$ & $* * *$ \\
\hline $\begin{array}{l}\text { Percentage of firms with } \\
\text { interest coverage }<2\end{array}$ & 56.61 & 49.48 & 50.70 & $* * *$ & $* *$ & NS & 50.33 & 60.37 & 46.40 & 53.84 & $* * *$ & $* * *$ & $* * *$ \\
\hline Asset Tangiblility & 0.42 & 0.31 & 0.49 & $* * *$ & $* * *$ & $* * *$ & 0.35 & 0.35 & 0.29 & 0.39 & NS & $* * *$ & $* * *$ \\
\hline Receivables to total assets & 0.29 & 0.34 & 0.16 & $* * *$ & $* * *$ & $* * *$ & 0.33 & 0.36 & 0.34 & 0.30 & $* * *$ & * & $* * *$ \\
\hline
\end{tabular}




\section{Table 4: Mean Summary Statistics, by Year. Balanced and Unbalanced Sample}

This table reports mean summary statistics by year on both balanced and unbalanced samples during the 1998-2002 period. A breakdown by size, age, sector, region and legal form categories is showed. In Agriculture sector missing category is fishing/forestry.

\begin{tabular}{|c|c|c|c|c|c|c|c|c|c|c|}
\hline \multirow[b]{3}{*}{$\begin{array}{l}\text { \# of Firms (with non-misssing } \\
\text { total assets) }\end{array}$} & \multicolumn{5}{|c|}{$\begin{array}{c}\text { Unbalanced Sample } \\
\text { MEAN }\end{array}$} & \multicolumn{5}{|c|}{$\begin{array}{c}\text { Balanced Sample } \\
\text { MEAN }\end{array}$} \\
\hline & 1998 & 1999 & 2000 & 2001 & 2002 & 1998 & 1999 & 2000 & 2001 & 2002 \\
\hline & 5,757 & 7,517 & 9,820 & 14,281 & 15,315 & 4,367 & 4,367 & 4,367 & 4,367 & 4,367 \\
\hline Age & 23.06 & 22.80 & 20.62 & 17.34 & 16.60 & 23.98 & 24.99 & 25.99 & 26.98 & 27.99 \\
\hline Total Assets (PLN) & 44,515 & 69,326 & 62,824 & 56,092 & 53,537 & 49,482 & 57,305 & 63,445 & 65,654 & 69,120 \\
\hline Total Sales (PLN) & 62,559 & 87,821 & 78,842 & 68,008 & 65,044 & 69,011 & 77,827 & 86,485 & 88,406 & 91,729 \\
\hline Debt to total assets & 0.16 & 0.17 & 0.18 & 0.16 & 0.11 & 0.18 & 0.20 & 0.20 & 0.20 & 0.15 \\
\hline Payables to total assets & 0.23 & 0.25 & 0.27 & 0.28 & 0.27 & 0.22 & 0.23 & 0.23 & 0.22 & 0.22 \\
\hline Liabilities to total assets & 0.56 & 0.59 & 0.61 & 0.63 & 0.64 & 0.58 & 0.60 & 0.61 & 0.61 & 0.62 \\
\hline Long-term debt to total assets & 0.06 & 0.08 & 0.07 & 0.06 & 0.04 & 0.09 & 0.09 & 0.08 & 0.08 & 0.05 \\
\hline Long-term debt to total debt & 0.32 & 0.31 & 0.31 & 0.29 & 0.28 & 0.32 & 0.31 & 0.29 & 0.28 & 0.24 \\
\hline Current Ratio & 1.73 & 1.63 & 1.67 & 1.73 & 1.72 & 1.76 & 1.69 & 1.66 & 1.70 & 1.59 \\
\hline $\begin{array}{l}\text { Percentage of firms with } \\
\text { interest coverage }<2\end{array}$ & 27.17 & 41.43 & 41.09 & 41.27 & 52.19 & 26.68 & 40.78 & 44.43 & 47.66 & 63.54 \\
\hline Asset Tangiblility & 0.40 & 0.40 & 0.38 & 0.36 & 0.36 & 0.42 & 0.41 & 0.40 & 0.40 & 0.42 \\
\hline Receivables to total assets & 0.27 & 0.29 & 0.30 & 0.31 & 0.32 & 0.27 & 0.28 & 0.29 & 0.29 & 0.28 \\
\hline EBIT/Sales & 0.02 & 0.01 & 0.00 & -0.01 & 0.00 & 0.03 & 0.02 & 0.02 & 0.01 & 0.00 \\
\hline Return on Assets & 0.09 & 0.07 & 0.05 & 0.04 & 0.05 & 0.10 & 0.07 & 0.06 & 0.04 & 0.03 \\
\hline \multicolumn{11}{|l|}{ Size Categories $* *$} \\
\hline$\%$ Micro & 10.48 & 10.99 & 19.08 & 29.52 & 34.73 & 8.95 & 8.47 & 7.33 & 6.50 & 7.53 \\
\hline$\%$ Small & 55.62 & 54.08 & 46.87 & 40.77 & 37.98 & 53.40 & 52.58 & 49.00 & 46.92 & 47.29 \\
\hline$\%$ Medium & 30.97 & 31.07 & 30.25 & 26.15 & 23.88 & 34.30 & 35.24 & 39.07 & 41.06 & 39.73 \\
\hline$\%$ Large & 2.93 & 3.87 & 3.81 & 3.56 & 3.4 & 3.34 & 3.71 & 4.60 & 5.52 & 5.45 \\
\hline \multicolumn{11}{|l|}{ Age Categories } \\
\hline$\%$ Age $0-1$ & 1.23 & 3.91 & 6.14 & 9.36 & 6.06 & 1.29 & 0.15 & 0.00 & 0.00 & 0.00 \\
\hline$\%$ Age $2-5$ & 25.22 & 18.45 & 18.62 & 19.59 & 22.5 & 24.89 & 16.91 & 11.21 & 5.56 & 1.29 \\
\hline$\%$ Age 6-10 & 36.27 & 40.79 & 39.37 & 36.12 & 31.66 & 34.76 & 42.09 & 44.03 & 42.58 & 35.42 \\
\hline$\%$ Age $>10$ & 37.28 & 36.85 & 35.87 & 34.93 & 39.78 & 39.06 & 40.85 & 44.76 & 51.92 & 63.29 \\
\hline \multicolumn{11}{|l|}{ Sector Types*** } \\
\hline$\%$ Manufacturing & 47.81 & 45.44 & 41.58 & 38.55 & 38 & 48.05 & 48.05 & 48.05 & 48.05 & 48.05 \\
\hline \% Services & 50.33 & 53.03 & 56.83 & 59.45 & 59.98 & 50.25 & 50.25 & 50.25 & 50.25 & 50.25 \\
\hline$\%$ Agriculture * & 1.8 & 1.48 & 1.53 & 1.89 & 1.85 & 1.67 & 1.67 & 1.67 & 1.67 & 1.67 \\
\hline \multicolumn{11}{|l|}{ Regions } \\
\hline \% Wielkopolskie & 10.50 & 10.36 & 9.20 & 11.14 & 11.79 & 10.35 & 10.35 & 10.35 & 10.35 & 10.35 \\
\hline$\%$ Slaskie & 13.01 & 13.06 & 11.06 & 8.73 & 10.68 & 13.49 & 13.49 & 13.49 & 13.49 & 13.49 \\
\hline$\%$ Mazowiecke & 21.60 & 22.55 & 24.89 & 26.32 & 25.86 & 22.60 & 22.60 & 22.60 & 22.60 & 22.60 \\
\hline$\%$ Others & 54.89 & 54.03 & 54.85 & 53.81 & 51.67 & 53.56 & 53.56 & 53.56 & 53.56 & 53.56 \\
\hline \multicolumn{11}{|l|}{$\begin{array}{l}\text { Legal Form } \\
\text { \% Limited Liability }\end{array}$} \\
\hline Partnerships & 49.39 & 49.69 & 53.34 & 59.73 & 62.75 & & & & & \\
\hline $\begin{array}{l}\text { \% Joint-Stock Companies } \\
\text { (listed/private) }\end{array}$ & 37.73 & 35.66 & 29.18 & 22.25 & 19.90 & & & & & \\
\hline
\end{tabular}


Table 5: Mean Summary Statistics by Year \& Size. Balanced and Unbalanced Sample

This table reports mean summary statistics across time according to size for both the balanced and unbalanced samples during the 1998-2002 period.

\begin{tabular}{|c|c|c|c|c|c|c|c|c|c|c|}
\hline & \multicolumn{5}{|c|}{ UNBALANCED MEAN } & \multicolumn{5}{|c|}{ BALANCED MEAN } \\
\hline & 1998 & 1999 & 2000 & 2001 & 2002 & 1998 & 1999 & 2000 & 2001 & 2002 \\
\hline $\begin{array}{l}\text { Micro Firms: } \\
\text { \# of Firms (with non-misssing total assets) }\end{array}$ & 602 & 824 & 1,872 & 4,214 & 5,321 & 391 & 370 & 320 & 284 & 329 \\
\hline Age & 15.60 & 15.53 & 9.81 & 8.21 & 8.36 & 15.31 & 17.61 & 18.19 & 19.40 & 19.91 \\
\hline Total Assets (PLN) & 9,723 & 8,712 & 4,161 & 2,390 & 2,265 & 10,669 & 5,717 & 3,715 & 2,514 & 11,679 \\
\hline Total Sales (PLN) & 4,015 & 4,174 & 3,161 & 2,777 & 3,099 & 3,712 & 4,320 & 4,244 & 3,633 & 4,582 \\
\hline Debt to total assets & 0.13 & 0.15 & 0.14 & 0.14 & 0.09 & 0.17 & 0.18 & 0.18 & 0.18 & 0.13 \\
\hline Payables to total assets & 0.19 & 0.22 & 0.27 & 0.31 & 0.31 & 0.20 & 0.20 & 0.22 & 0.22 & 0.20 \\
\hline Liabilities to total assets & 0.54 & 0.57 & 0.61 & 0.66 & 0.67 & 0.60 & 0.64 & 0.66 & 0.66 & 0.65 \\
\hline Long-term debt to total assets & 0.05 & 0.06 & 0.06 & 0.05 & 0.03 & 0.12 & 0.11 & 0.10 & 0.07 & 0.07 \\
\hline Long-term debt to total debt & 0.33 & 0.33 & 0.31 & 0.30 & 0.31 & 0.37 & 0.35 & 0.28 & 0.26 & 0.30 \\
\hline Current Ratio & 2.36 & 2.30 & 2.32 & 2.20 & 2.12 & 2.38 & 2.31 & 2.22 & 2.28 & 2.29 \\
\hline Percentage of firms with interest coverage $<2$ & 18.77 & 34.71 & 25.75 & 27.12 & 37.04 & 18.93 & 35.41 & 38.13 & 38.73 & 58.36 \\
\hline Asset Tangiblility & 0.38 & 0.36 & 0.31 & 0.30 & 0.29 & 0.34 & 0.35 & 0.34 & 0.32 & 0.34 \\
\hline Receivables to total assets & 0.26 & 0.28 & 0.32 & 0.34 & 0.36 & 0.27 & 0.28 & 0.31 & 0.31 & 0.29 \\
\hline EBIT/Sales & 0.04 & 0.07 & 0.03 & 0.04 & 0.01 & -0.05 & -0.04 & -0.02 & -0.06 & -0.10 \\
\hline Return on Assets & 0.03 & 0.00 & 0.03 & 0.02 & 0.04 & 0.02 & 0.00 & 0.00 & -0.04 & -0.05 \\
\hline $\begin{array}{l}\text { Small Firms: } \\
\text { \# of Firms (with non-misssing total assets) }\end{array}$ & 3,201 & 4.067 & 4.604 & 5.822 & 5.814 & 2332 & 2296 & 2140 & 2049 & 2065 \\
\hline Age & 21.37 & 20.89 & 21.08 & 18.60 & 18.58 & 21.77 & 23.67 & 25.09 & 26.15 & 27.77 \\
\hline Total Assets (PLN) & 14,048 & 15,353 & 15,949 & 15,217 & 15,816 & 15,360 & 16,933 & 16,427 & 16,540 & 17,015 \\
\hline Total Sales (PLN) & 19,731 & 21,723 & 21,436 & 18,818 & 18,790 & 20,389 & 22,407 & 22,250 & 20,384 & 20,289 \\
\hline Debt to total assets & 0.14 & 0.16 & 0.16 & 0.15 & 0.11 & 0.17 & 0.18 & 0.18 & 0.17 & 0.14 \\
\hline Payables to total assets & 0.22 & 0.24 & 0.25 & 0.26 & 0.26 & 0.21 & 0.21 & 0.21 & 0.20 & 0.21 \\
\hline Liabilities to total assets & 0.54 & 0.57 & 0.58 & 0.61 & 0.61 & 0.57 & 0.58 & 0.58 & 0.58 & 0.61 \\
\hline Long-term debt to total assets & 0.06 & 0.06 & 0.06 & 0.06 & 0.04 & 0.08 & 0.08 & 0.08 & 0.07 & 0.05 \\
\hline Long-term debt to total debt & 0.32 & 0.32 & 0.31 & 0.28 & 0.29 & 0.33 & 0.31 & 0.30 & 0.28 & 0.23 \\
\hline Current Ratio & 1.76 & 1.64 & 1.62 & 1.63 & 1.59 & 1.82 & 1.74 & 1.77 & 1.78 & 1.60 \\
\hline Percentage of firms with interest coverage $<2$ & 22.74 & 39.49 & 40.18 & 42.61 & 56.24 & 21.52 & 38.64 & 39.38 & 43.50 & 63.48 \\
\hline Asset Tangiblility & 0.41 & 0.40 & 0.39 & 0.38 & 0.39 & 0.43 & 0.42 & 0.41 & 0.42 & 0.43 \\
\hline Receivables to total assets & 0.27 & 0.28 & 0.29 & 0.30 & 0.30 & 0.26 & 0.27 & 0.28 & 0.27 & 0.26 \\
\hline EBIT/Sales & 0.03 & 0.03 & 0.01 & 0.00 & 0.01 & 0.04 & 0.03 & 0.02 & 0.00 & 0.00 \\
\hline Return on Assets & 0.11 & 0.08 & 0.06 & 0.04 & 0.05 & 0.11 & 0.08 & 0.06 & 0.03 & 0.03 \\
\hline $\begin{array}{l}\text { Medium Firms: } \\
\text { \# of Firms (with non-misssing total assets) }\end{array}$ & 1,785 & 2,335 & 2,970 & 3,737 & 3,659 & 1498 & 1539 & 1706 & 1793 & 1735 \\
\hline Age & 27.24 & 26.82 & 24.93 & 23.04 & 23.03 & 28.39 & 28.04 & 27.84 & 28.11 & 28.91 \\
\hline Total Assets (PLN) & 57,078 & 69,938 & 62,061 & 58,146 & 62,908 & 58,879 & 68,933 & 63,942 & 58,992 & 65,633 \\
\hline Total Sales (PLN) & 89,859 & 102,094 & 96,989 & 89,199 & 93,022 & 90,442 & 96,148 & 95,865 & 88,042 & 92,246 \\
\hline Debt to total assets & 0.19 & 0.20 & 0.20 & 0.20 & 0.13 & 0.21 & 0.22 & .2231423 & 0.22 & 0.16 \\
\hline Payables to total assets & 0.27 & 0.28 & 0.29 & 0.29 & 0.27 & 0.26 & 0.27 & 0.27 & 0.25 & 0.24 \\
\hline Liabilities to total assets & 0.60 & 0.62 & 0.64 & 0.64 & 0.64 & 0.59 & 0.62 & 0.63 & 0.63 & 0.64 \\
\hline Long-term debt to total assets & 0.07 & 0.07 & 0.07 & 0.07 & 0.04 & 0.09 & 0.09 & 0.08 & 0.08 & 0.05 \\
\hline Long-term debt to total debt & 0.29 & 0.29 & 0.29 & 0.27 & 0.26 & 0.30 & 0.30 & 0.27 & 0.26 & 0.23 \\
\hline Current Ratio & 1.51 & 1.43 & 1.38 & 1.43 & 1.41 & 1.54 & 1.51 & 1.47 & 1.55 & 1.48 \\
\hline Percentage of firms with interest coverage $<2$ & 36.69 & 46.25 & 50.64 & 52.90 & 64.96 & 35.58 & 44.10 & 50.38 & 52.37 & 64.27 \\
\hline Asset Tangiblility & 0.39 & 0.39 & 0.38 & 0.37 & 0.39 & 0.40 & 0.39 & 0.39 & 0.39 & 0.41 \\
\hline Receivables to total assets & 0.29 & 0.30 & 0.32 & 0.32 & 0.31 & 0.28 & 0.30 & 0.31 & 0.32 & 0.30 \\
\hline EBIT/Sales & 0.03 & 0.02 & 0.01 & 0.01 & 0.01 & 0.03 & 0.02 & 0.02 & 0.02 & 0.02 \\
\hline Return on Assets & 0.10 & 0.07 & 0.06 & 0.05 & 0.05 & 0.10 & 0.08 & 0.07 & 0.06 & 0.05 \\
\hline $\begin{array}{l}\text { Large Firms } \\
\# \text { of Firms (with non-misssir }\end{array}$ & & & & & & & 162 & & & \\
\hline Age & 35.20 & 35.36 & 33.04 & 35.29 & 34.01 & 34.53 & 30.64 & 31.58 & 34.08 & 33.81 \\
\hline Total Assets (PLN) & 612,840 & 990,365 & 939,542 & 954,906 & 932,300 & 602,044 & 636,858 & 654,913 & 607,195 & 626,020 \\
\hline Total Sales (PLN) & 797,403 & $1,130,371$ & $1,010,506$ & $1,009,084$ & $1,008,975$ & 799,664 & 856,669 & 819,397 & 766,003 & 819,763 \\
\hline Debt to total assets & 0.21 & 0.23 & 0.23 & 0.22 & 0.12 & 0.21 & 0.25 & .2630569 & 0.25 & 0.14 \\
\hline Payables to total assets & 0.19 & 0.20 & 0.21 & 0.19 & 0.18 & 0.19 & 0.22 & 0.22 & 0.20 & 0.20 \\
\hline Liabilities to total assets & 0.53 & 0.57 & 0.59 & 0.61 & 0.60 & 0.50 & 0.60 & 0.61 & 0.64 & 0.61 \\
\hline Long-term debt to total assets & 0.09 & 0.10 & 0.10 & 0.10 & 0.05 & 0.09 & 0.13 & 0.14 & 0.12 & 0.05 \\
\hline Long-term debt to total debt & 0.36 & 0.39 & 0.37 & 0.36 & 0.30 & 0.39 & 0.39 & 0.36 & 0.33 & 0.27 \\
\hline Current Ratio & 1.22 & 1.24 & 1.35 & 1.29 & 1.32 & 1.26 & 1.25 & 1.28 & 1.35 & 1.26 \\
\hline Percentage of firms with interest coverage $<2$ & 39.05 & 49.48 & 53.48 & 57.87 & 72.36 & 38.36 & 51.85 & 57.71 & 58.51 & 65.97 \\
\hline Asset Tangiblility & 0.52 & 0.49 & 0.45 & 0.46 & 0.46 & 0.52 & 0.51 & 0.48 & 0.47 & 0.47 \\
\hline Receivables to total assets & 0.21 & 0.22 & 0.24 & 0.24 & 0.24 & 0.21 & 0.22 & 0.24 & 0.24 & 0.23 \\
\hline EBIT/Sales & 0.03 & 0.03 & 0.03 & 0.01 & 0.02 & 0.03 & 0.03 & 0.03 & 0.01 & 0.02 \\
\hline Return on Assets & 0.05 & 0.05 & 0.04 & 0.03 & 0.04 & 0.05 & 0.05 & 0.04 & 0.04 & 0.05 \\
\hline
\end{tabular}


Table 6: Balanced Sample Growth Rates, by Year

This table reports mean and median growth rates on size, profitability and financial structure for the balanced sample. All financial ratios are corrected for outliers at the $1 \%$ or $5 \%$ critical levels. All Firm mean and median figures for year 2002 based on unbalanced sample.

\begin{tabular}{|c|c|c|c|c|c|c|c|c|c|c|c|c|}
\hline & \multicolumn{2}{|c|}{ All Firms } & \multicolumn{10}{|c|}{ Balanced Sample } \\
\hline & $\begin{array}{l}\text { Mean } \\
2002\end{array}$ & $\begin{array}{c}\text { Median } \\
2002\end{array}$ & 1998 & 1999 & $\begin{array}{l}\text { Mean } \\
2000\end{array}$ & 2001 & 2002 & 1998 & 1999 & $\begin{array}{c}\text { Median } \\
2000\end{array}$ & 2001 & 2002 \\
\hline \multicolumn{13}{|l|}{ Nominal growth rate of } \\
\hline$\overline{\text { Total Assets (\%) }}$ & 17.10 & 5.05 & 25.36 & 19.22 & 14.36 & 5.10 & 9.95 & 11.38 & 9.63 & 6.18 & 1.25 & 3.96 \\
\hline Sales $(\%)$ & 24.18 & 2.65 & 26.60 & 15.15 & 14.26 & 3.94 & 3.86 & 12.59 & 8.07 & 7.34 & 0.00 & 0.02 \\
\hline Earnings (before interest and tax) (\%) & -120.76 & -20.55 & -58.67 & -92.76 & -126.36 & -76.00 & -142.58 & -10.81 & -15.59 & -22.93 & -27.92 & -23.46 \\
\hline Payables (\%) & 46.79 & 3.41 & 61.80 & 59.59 & 45.34 & 20.99 & 27.15 & 15.98 & 20.61 & 12.88 & 1.20 & 2.95 \\
\hline Total Debt (\%) & 37.78 & -13.84 & 130.21 & 85.42 & 92.02 & 33.92 & 3.27 & 24.44 & 12.77 & 7.80 & -4.35 & -16.77 \\
\hline Liabilities (\%) & 27.38 & 6.39 & 38.34 & 33.67 & 19.97 & 8.04 & 17.59 & 16.74 & 16.02 & 7.77 & -0.30 & 4.18 \\
\hline \multicolumn{13}{|l|}{ Small Firms: } \\
\hline Total Assets (\%) & 14.89 & 4.97 & 21.75 & 17.00 & 12.78 & 3.68 & 7.66 & 9.99 & 8.72 & 4.87 & -0.34 & 3.27 \\
\hline Sales $(\%)$ & 16.48 & 1.31 & 21.51 & 12.38 & 10.66 & -0.82 & 1.34 & 10.86 & 5.94 & 5.05 & -2.75 & -2.62 \\
\hline Earnings (before interest and tax) (\%) & -97.24 & -19.32 & -100.56 & -104.07 & -65.10 & -62.96 & -105.99 & -13.62 & -16.64 & -23.08 & -35.37 & -26.77 \\
\hline Payables (\%) & 38.61 & 2.41 & 60.70 & 58.08 & 45.35 & 22.59 & 19.25 & 14.76 & 20.43 & 10.84 & 0.95 & -0.03 \\
\hline Total Debt (\%) & 42.69 & -12.13 & 116.48 & 74.14 & 100.94 & 36.30 & -2.19 & 18.29 & 8.71 & 9.06 & -7.70 & -17.47 \\
\hline Liabilities (\%) & 22.98 & 6.75 & 36.63 & 30.40 & 17.83 & 6.52 & 16.25 & 14.24 & 13.05 & 5.58 & -2.09 & 3.61 \\
\hline \multicolumn{13}{|l|}{ Medium and Large Firms } \\
\hline Total Assets (\%) & 18.60 & 7.75 & 29.24 & 23.05 & 16.32 & 7.25 & 13.02 & 13.93 & 11.67 & 8.48 & 3.19 & 5.89 \\
\hline Sales $(\%)$ & 22.07 & 6.12 & 30.41 & 18.78 & 18.17 & 7.55 & 8.33 & 15.16 & 11.44 & 9.94 & 4.08 & 3.35 \\
\hline Earnings (before interest and tax) $(\%)$ & -128.02 & -11.42 & -18.85 & -83.59 & -209.52 & -79.18 & -148.09 & -5.88 & -9.20 & -20.92 & -18.20 & -16.96 \\
\hline Payables (\%) & 43.32 & 8.63 & 50.01 & 60.75 & 42.32 & 17.16 & 33.76 & 15.85 & 20.78 & 14.77 & 1.83 & 7.51 \\
\hline Total Debt (\%) & 38.42 & -12.99 & 145.33 & 94.00 & 87.55 & 33.71 & 7.68 & 31.56 & 17.56 & 7.98 & -2.32 & -16.88 \\
\hline Liabilities (\%) & 26.90 & 9.04 & 37.20 & 39.11 & 21.49 & 9.83 & 19.44 & 20.22 & 20.55 & 10.60 & 1.43 & 6.14 \\
\hline \multicolumn{13}{|l|}{ Manufacturing Firms } \\
\hline$\overline{\text { Total Assets (\%) }}$ & 15.78 & 5.28 & 19.69 & 15.28 & 10.25 & 4.31 & 8.62 & 8.34 & 6.51 & 4.33 & 1.24 & 3.69 \\
\hline Sales $(\%)$ & 21.47 & 3.67 & 18.61 & 10.82 & 12.87 & 4.24 & 4.00 & 9.41 & 4.34 & 7.08 & 1.24 & 0.76 \\
\hline Earnings (before interest and tax) (\%) & -122.95 & -18.21 & -71.86 & -74.02 & -75.66 & -53.45 & -73.30 & -19.64 & -15.54 & -29.28 & -28.80 & -22.08 \\
\hline Payables (\%) & 44.28 & 5.54 & 45.72 & 49.35 & 38.03 & 20.32 & 27.60 & 11.19 & 18.08 & 12.80 & 3.20 & 4.35 \\
\hline Total Debt (\%) & 35.26 & -13.78 & 112.99 & 78.56 & 73.62 & 32.26 & 3.47 & 22.96 & 13.18 & 4.76 & -4.72 & -17.12 \\
\hline Liabilities (\%) & 23.65 & 7.30 & 36.11 & 32.08 & 17.00 & 8.32 & 15.09 & 16.66 & 15.07 & 6.17 & -0.16 & 5.92 \\
\hline \multicolumn{13}{|l|}{ Service Firms } \\
\hline Total Assets (\%) & 18.10 & 5.05 & 31.69 & 23.84 & 18.84 & 5.91 & 11.40 & 15.20 & 14.03 & 8.51 & 1.17 & 4.13 \\
\hline Sales $(\%)$ & 26.34 & 2.12 & 35.71 & 20.18 & 15.74 & 3.68 & 3.75 & 16.74 & 12.43 & 7.56 & -1.03 & -1.02 \\
\hline Earnings (before interest and tax) (\%) & -121.73 & -22.06 & -45.15 & -114.72 & -185.28 & -100.04 & -218.41 & 0.12 & -15.56 & -16.93 & -27.23 & -24.56 \\
\hline Payables (\%) & 47.84 & 1.48 & 77.57 & 70.36 & 53.81 & 21.04 & 26.94 & 19.61 & 23.82 & 13.13 & -0.41 & 1.67 \\
\hline Total Debt (\%) & 40.04 & -14.69 & 162.68 & 98.82 & 123.67 & 37.05 & 2.98 & 30.08 & 11.69 & 16.73 & -4.31 & -18.14 \\
\hline Liabilities (\%) & 30.43 & 5.83 & 42.99 & 37.38 & 24.69 & 6.84 & 20.82 & 17.80 & 18.62 & 11.02 & -1.15 & 2.59 \\
\hline
\end{tabular}




\section{Table 7: Fixed Effects and Pooled OLS Regressions}

This table reports Fixed Effects and Pooled regression results. Concentration (sum of the 5 largest firms' total sales divided by the total sales in the industry) is a measure if industry concentration. Robust $t$ statistics are in brackets. Significance at $1 \%, 5 \%$ and $10 \%$ levels is represented as $* * *$, **, * respectively.

\begin{tabular}{|c|c|c|c|c|c|c|c|c|}
\hline & \multicolumn{4}{|c|}{ Fixed Effects } & \multicolumn{4}{|c|}{ Pooled } \\
\hline & Debt/Asset & STDebt/Asset & LTDebt/Asset & Payables/Asset & Debt/Asset & STDebt/Asset & LTDebt/Asset & Payables/Asset \\
\hline \multirow[t]{2}{*}{ Ln(Sales) } & 0.005 & 0.005 & -0.019 & 0.025 & 0.018 & 0.012 & 0.005 & 0.02 \\
\hline & {$[0.61]$} & {$[0.83]$} & {$[1.82]^{*}$} & {$[4.37]^{* * *}$} & {$[8.40]^{* * *}$} & {$[8.60]^{* * *}$} & {$[1.97]^{* *}$} & {$[10.27]^{* * *}$} \\
\hline \multirow[t]{2}{*}{ Lnage } & -0.081 & 0.001 & -0.13 & -0.085 & -0.032 & -0.007 & -0.038 & -0.037 \\
\hline & {$[3.70]^{* * *}$} & {$[0.04]$} & {$[4.40] * * *$} & {$[5.18]^{* * *}$} & {$[13.07]^{* * *}$} & {$[4.14]^{* * *}$} & {$[15.20]^{* * *}$} & {$[17.45]^{* * *}$} \\
\hline \multirow[t]{2}{*}{ ROA } & -0.192 & -0.144 & -0.078 & -0.247 & -0.142 & -0.101 & -0.086 & -0.38 \\
\hline & {$[9.02]^{* * *}$} & {$[7.50]^{* * *}$} & {$[2.08]^{* *}$} & {$[14.46]^{* * *}$} & {$[10.30]^{* * *}$} & {$[10.02]^{* * *}$} & {$[4.64] * * *$} & {$[26.21]^{* * *}$} \\
\hline \multirow[t]{2}{*}{ Fixed Assets/Assets } & 0.145 & -0.007 & 0.177 & -0.201 & 0.119 & -0.046 & 0.198 & -0.41 \\
\hline & {$[5.32] * * *$} & {$[0.36]$} & {$[4.48]^{* * *}$} & {$[10.25]^{* * *}$} & {$[9.73] * * *$} & {$[6.49]^{* * *}$} & {$[14.00]^{* * *}$} & {$[42.43]^{* * *}$} \\
\hline \multirow[t]{2}{*}{ Sales Growth } & 0.004 & 0.001 & 0.003 & 0.007 & 0.01 & 0.001 & 0.015 & 0.006 \\
\hline & {$[1.21]$} & {$[0.58]$} & {$[0.85]$} & {$[3.22]^{* * *}$} & {$[4.10]^{* * *}$} & {$[0.43]$} & {$[5.17]^{* * *}$} & {$[3.04] * * *$} \\
\hline \multirow[t]{2}{*}{ Depreciation/Assets } & -0.196 & 0.018 & -0.274 & -0.201 & 0.084 & 0.109 & -0.017 & -0.165 \\
\hline & {$[1.90]^{*}$} & {$[0.21]$} & {$[2.06] * *$} & {$[2.21]^{* *}$} & [1.18] & {$[2.56] * *$} & {$[0.21]$} & {$[3.03] * * *$} \\
\hline \multirow[t]{2}{*}{ Concentration } & 0.048 & 0.004 & 0.081 & 0.027 & 0.093 & 0.034 & 0.093 & 0.012 \\
\hline & {$[2.06] * *$} & {$[0.18]$} & {$[2.76]^{* * *}$} & {$[1.42]$} & {$[3.83]^{* * *}$} & {$[1.87]^{*}$} & {$[3.18]^{* * *}$} & {$[0.61]$} \\
\hline \multirow[t]{2}{*}{ Constant } & 0.268 & 0.068 & 0.525 & 0.347 & -0.115 & -0.038 & -0.052 & 0.171 \\
\hline & {$[3.33]^{* * *}$} & {$[1.07]$} & {$[4.66]^{* * *}$} & {$[5.90] * * *$} & {$[2.77] * * *$} & {$[1.17]$} & {$[1.04]$} & {$[2.79] * * *$} \\
\hline Industry Dummies & Yes & Yes & Yes & Yes & Yes & Yes & Yes & Yes \\
\hline Year Dummies & Yes & Yes & Yes & Yes & Yes & Yes & Yes & Yes \\
\hline Observations & 17,767 & 16,906 & 10,140 & 19,324 & 17,767 & 16,906 & 10,140 & 19,324 \\
\hline R-squared & 0.81 & 0.78 & 0.81 & 0.9 & 0.13 & 0.12 & 0.15 & 0.44 \\
\hline
\end{tabular}




\section{Table 8: Pooled OLS Regressions}

This table incorporates in the Pooled OLS regression three subsets of dummy variables; size (small and medium, being large the omitted category), ownership (foreign, government, keeping private domestic firms as the omitted variable), and region (keeping "other regions" unspecified). Concentration (sum of the 5 largest firms' total sales divided by the total sales in the industry) is a measure if industry concentration. Robust $t$ statistics are in brackets. Significance at $1 \%, 5 \%$ and $10 \%$ levels is represented as $* * *, * *, *$ respectively.

\begin{tabular}{|c|c|c|c|c|}
\hline & \multicolumn{4}{|c|}{ Pooled } \\
\hline & Debt/Asset & STDebt/Asset & LTDebt/Asset & Payables/Asset \\
\hline Small & $\begin{array}{l}0.028 \\
{[1.29]}\end{array}$ & $\begin{array}{l}0.047 \\
{[3.01] * * *}\end{array}$ & $\begin{array}{l}-0.034 \\
{[1.41]}\end{array}$ & $\begin{array}{l}0.057 \\
{[2.61] * * *}\end{array}$ \\
\hline Medium & $\begin{array}{l}0.028 \\
{[1.60]}\end{array}$ & $\begin{array}{l}0.04 \\
{[3.14] * * *}\end{array}$ & $\begin{array}{l}-0.019 \\
{[0.97]}\end{array}$ & $\begin{array}{l}0.046 \\
{[2.55]^{* *}}\end{array}$ \\
\hline Foreign & $\begin{array}{l}0.017 \\
{[1.75]^{*}}\end{array}$ & $\begin{array}{l}-0.002 \\
{[0.21]}\end{array}$ & $\begin{array}{l}0.053 \\
{[4.42]^{* * *}}\end{array}$ & $\begin{array}{l}-0.048 \\
{[4.96]^{* * *}}\end{array}$ \\
\hline Government & $\begin{array}{l}-0.106 \\
{[9.29]^{* * *}}\end{array}$ & $\begin{array}{l}-0.042 \\
{[5.49] * * *}\end{array}$ & $\begin{array}{l}-0.081 \\
{[6.50]^{* * *}}\end{array}$ & $\begin{array}{l}-0.111 \\
{[11.40]^{* * *}}\end{array}$ \\
\hline Wielkopolskie & $\begin{array}{l}0.001 \\
{[0.15]}\end{array}$ & $\begin{array}{l}-0.002 \\
{[0.23]}\end{array}$ & $\begin{array}{l}-0.005 \\
{[0.55]}\end{array}$ & $\begin{array}{l}0.001 \\
{[0.13]}\end{array}$ \\
\hline Mazoweicke & $\begin{array}{l}0.003 \\
{[0.40]}\end{array}$ & $\begin{array}{l}-0.009 \\
{[1.45]}\end{array}$ & $\begin{array}{l}0.028 \\
{[2.71]^{* * *}}\end{array}$ & $\begin{array}{l}-0.005 \\
{[0.62]}\end{array}$ \\
\hline Slaskie & $\begin{array}{l}-0.034 \\
{[3.39]^{* * *}}\end{array}$ & $\begin{array}{l}-0.023 \\
{[2.94]^{* * *}}\end{array}$ & $\begin{array}{l}-0.014 \\
{[1.35]}\end{array}$ & $\begin{array}{l}0.006 \\
{[0.51]}\end{array}$ \\
\hline Ln Sales & $\begin{array}{l}0.018 \\
{[3.61]^{* * *}}\end{array}$ & $\begin{array}{l}0.02 \\
{[5.38]^{* * *}}\end{array}$ & $\begin{array}{l}-0.006 \\
{[1.15]}\end{array}$ & $\begin{array}{l}0.025 \\
{[5.28]^{* * *}}\end{array}$ \\
\hline Ln Age & $\begin{array}{l}-0.013 \\
{[3.02]^{* * *}}\end{array}$ & $\begin{array}{l}-0.003 \\
{[0.89]}\end{array}$ & $\begin{array}{l}-0.017 \\
{[3.66]^{* * *}}\end{array}$ & $\begin{array}{l}-0.023 \\
{[6.22]^{* * *}}\end{array}$ \\
\hline ROA & $\begin{array}{l}-0.176 \\
{[7.90]^{* * *}}\end{array}$ & $\begin{array}{l}-0.13 \\
{[7.38]^{* * *}}\end{array}$ & $\begin{array}{l}-0.064 \\
{[2.54]^{* *}}\end{array}$ & $\begin{array}{l}-0.38 \\
{[15.87]^{* * *}}\end{array}$ \\
\hline Fixed Asset/Asset & $\begin{array}{l}0.143 \\
{[7.71]^{* * *}}\end{array}$ & $\begin{array}{l}-0.032 \\
{[2.81]^{* * *}}\end{array}$ & $\begin{array}{l}0.209 \\
{[9.49]^{* * *}}\end{array}$ & $\begin{array}{l}-0.359 \\
{[22.70]^{* * *}}\end{array}$ \\
\hline Sales Growth & $\begin{array}{l}0.007 \\
{[2.13]^{* *}}\end{array}$ & $\begin{array}{l}0 \\
{[0.19]}\end{array}$ & $\begin{array}{l}0.013 \\
{[2.83]^{* * *}}\end{array}$ & $\begin{array}{l}0.007 \\
{[2.15]^{* *}}\end{array}$ \\
\hline Depreciation/Assets & $\begin{array}{l}-0.009 \\
{[0.09]}\end{array}$ & $\begin{array}{l}0.113 \\
{[1.78]^{*}}\end{array}$ & $\begin{array}{l}-0.148 \\
{[1.40]}\end{array}$ & $\begin{array}{l}-0.203 \\
{[2.40]^{* *}}\end{array}$ \\
\hline Concentration & $\begin{array}{l}0.075 \\
{[2.21]^{* *}}\end{array}$ & $\begin{array}{l}0.019 \\
{[0.76]}\end{array}$ & $\begin{array}{l}0.1 \\
{[2.19]^{* *}}\end{array}$ & $\begin{array}{l}0.049 \\
{[1.87]^{*}}\end{array}$ \\
\hline Constant & $\begin{array}{l}-0.101 \\
{[1.37]}\end{array}$ & $\begin{array}{l}-0.123 \\
{[2.19]^{* *}}\end{array}$ & $\begin{array}{l}0.064 \\
{[0.76]}\end{array}$ & $\begin{array}{l}0.064 \\
{[0.83]}\end{array}$ \\
\hline Industry Dummies & Yes & Yes & Yes & Yes \\
\hline Year Dummies & Yes & Yes & Yes & Yes \\
\hline Observations & 7,312 & 6,985 & 4,034 & 7,970 \\
\hline R-squared & 0.18 & 0.16 & 0.2 & 0.48 \\
\hline
\end{tabular}


Table 9: Pooled OLS Regression by Firm Size

This table incorporates Pooled OLS regressions with size breakdown. Concentration ( sum of the 5 largest firms' total sales divided by the total sales in the industry) is a measure if industry concentration. Robust $\mathrm{t}$ statistics are in brackets. Significance at $1 \%, 5 \%$ and $10 \%$ levels is represented as $* * *, * *$, $*$ respectively.

Table R3: Financing Ratios by Firm Size

\begin{tabular}{|c|c|c|c|c|c|c|c|c|c|c|c|c|}
\hline & \multicolumn{12}{|c|}{ Pooled } \\
\hline & \multicolumn{3}{|c|}{ Debt/Asset } & \multicolumn{3}{|c|}{ STDebt/Asset } & \multicolumn{3}{|c|}{ LTDebt/Asset } & \multicolumn{3}{|c|}{ Payables/Asset } \\
\hline & Small & Medium & Large & Small & Medium & Large & Small & Medium & Large & Small & Medium & Large \\
\hline \multirow[t]{2}{*}{ Foreign } & 0.027 & 0.018 & -0.066 & -0.011 & 0.005 & -0.002 & 0.077 & 0.052 & -0.091 & -0.017 & -0.075 & -0.146 \\
\hline & {$[2.18]^{* *}$} & {$[1.22]$} & {$[1.20]$} & {$[1.26]$} & {$[0.40]$} & {$[0.08]$} & {$[5.20]^{* * *}$} & {$[2.95]^{* * *}$} & [1.38] & {$[1.25]$} & {$[5.65]^{* * *}$} & {$[2.92] * * *$} \\
\hline \multirow[t]{2}{*}{ Government } & -0.101 & -0.112 & -0.122 & -0.047 & -0.04 & -0.013 & -0.071 & -0.087 & -0.171 & -0.104 & -0.12 & -0.239 \\
\hline & {$[8.03]^{* * *}$} & {$[5.51]^{* * *}$} & {$[2.04]^{* *}$} & {$[5.37] * * *$} & {$[2.78]^{* * *}$} & {$[0.35]$} & {$[5.75]^{* * *}$} & {$[4.30]^{* * *}$} & {$[2.42]^{* *}$} & {$[8.67] * * *$} & {$[8.17]^{* * *}$} & {$[3.92] * * *$} \\
\hline \multirow[t]{2}{*}{ Wielkopolskie } & -0.019 & 0.024 & 0.061 & -0.017 & 0.011 & 0.075 & -0.007 & 0.008 & -0.075 & 0.007 & -0.007 & 0.021 \\
\hline & {$[1.69]^{*}$} & [1.39] & {$[1.73]^{*}$} & {$[2.14]^{* *}$} & {$[0.75]$} & {$[3.57]^{* * *}$} & {$[0.70]$} & {$[0.55]$} & {$[1.67]^{*}$} & {$[0.57]$} & {$[0.44]$} & {$[0.68]$} \\
\hline \multirow[t]{2}{*}{ Mazoweicke } & -0.012 & 0.026 & 0.017 & -0.024 & 0.007 & 0.025 & 0.028 & 0.037 & 0.002 & 0.001 & -0.009 & 0.006 \\
\hline & {$[1.23]$} & {$[1.72]^{*}$} & {$[0.47]$} & {$[3.45]^{* * *}$} & {$[0.68]$} & {$[1.26]$} & {$[2.42]^{* *}$} & {$[2.18]^{* *}$} & {$[0.04]$} & {$[0.09]$} & {$[0.66]$} & {$[0.21]$} \\
\hline \multirow[t]{2}{*}{ Slaskie } & -0.04 & -0.026 & -0.041 & -0.032 & -0.012 & -0.024 & -0.017 & -0.019 & -0.004 & -0.008 & 0.005 & 0.117 \\
\hline & {$[3.44]^{* * *}$} & [1.59] & {$[1.02]$} & {$[3.49]^{* * *}$} & [0.89] & {$[0.94]$} & {$[1.37]$} & {$[1.23]$} & {$[0.10]$} & {$[0.59]$} & {$[0.32]$} & [1.64] \\
\hline \multirow[t]{2}{*}{ Ln Sales } & 0.016 & 0.024 & 0.015 & 0.021 & 0.023 & 0 & -0.019 & 0.004 & 0.007 & 0.031 & 0.02 & 0.011 \\
\hline & {$[2.18]^{* *}$} & {$[2.98]^{* * *}$} & {$[0.71]$} & {$[4.23]^{* * *}$} & {$[3.65]^{* * *}$} & {$[0.01]$} & {$[2.03]^{* *}$} & {$[0.47]$} & {$[0.38]$} & {$[4.16]^{* * *}$} & {$[2.89]^{* * *}$} & {$[0.71]$} \\
\hline \multirow[t]{2}{*}{ Ln Age } & -0.008 & -0.013 & -0.026 & 0.002 & -0.004 & -0.011 & -0.013 & -0.016 & -0.025 & -0.018 & -0.032 & -0.003 \\
\hline & {$[1.42]$} & {$[1.96]^{*}$} & {$[1.63]$} & {$[0.48]$} & {$[0.86]$} & {$[1.24]$} & {$[2.50]^{* *}$} & {$[2.27]^{* *}$} & {$[1.33]$} & {$[3.65]^{* * *}$} & {$[5.98]^{* * *}$} & {$[0.19]$} \\
\hline \multirow[t]{2}{*}{ ROA } & -0.139 & -0.193 & -0.338 & -0.12 & -0.13 & -0.233 & -0.01 & -0.107 & -0.112 & -0.383 & -0.373 & -0.35 \\
\hline & {$[4.95]^{* * *}$} & {$[5.45]^{* * *}$} & {$[2.85]^{* * *}$} & {$[5.54]^{* * *}$} & {$[4.61]^{* * *}$} & {$[2.75]^{* * *}$} & {$[0.31]$} & {$[2.45]^{* *}$} & {$[0.79]$} & {$[12.55] * * *$} & {$[10.30]^{* * *}$} & {$[2.51]^{* *}$} \\
\hline \multirow[t]{2}{*}{ Fixed Asset/Asset } & 0.136 & 0.178 & -0.038 & -0.023 & -0.024 & -0.179 & 0.185 & 0.237 & 0.144 & -0.321 & -0.422 & -0.298 \\
\hline & {$[6.61]^{* * *}$} & {$[5.42]^{* * *}$} & {$[0.45]$} & {$[1.84]^{*}$} & {$[1.14]$} & {$[3.63]^{* * *}$} & {$[7.63]^{* * *}$} & {$[6.69]^{* * *}$} & {$[1.23]$} & {$[16.31]^{* * *}$} & {$[16.79]^{* * *}$} & {$[4.22]^{* * *}$} \\
\hline \multirow[t]{2}{*}{ Sales Growth } & 0.007 & 0.011 & -0.007 & -0.002 & 0.002 & 0.003 & 0.014 & 0.019 & -0.014 & 0.012 & -0.001 & 0.008 \\
\hline & {$[1.52]$} & {$[1.96]^{*}$} & {$[0.67]$} & {$[0.65]$} & {$[0.68]$} & {$[0.35]$} & {$[2.60]^{* * *}$} & {$[2.53]^{* *}$} & [1.62] & {$[2.75]^{* * *}$} & {$[0.13]$} & {$[0.73]$} \\
\hline \multirow[t]{2}{*}{ Depreciation/Asset } & -0.028 & 0.077 & 0.083 & -0.003 & 0.286 & 0.335 & -0.013 & -0.247 & -0.295 & -0.251 & -0.267 & 0.148 \\
\hline & {$[0.26]$} & {$[0.41]$} & {$[0.19]$} & {$[0.04]$} & {$[2.34]^{* *}$} & {$[0.92]$} & {$[0.11]$} & {$[1.24]$} & {$[0.80]$} & {$[2.45]^{* *}$} & {$[1.73]^{*}$} & {$[0.37]$} \\
\hline \multirow[t]{2}{*}{ Concentration } & 0.041 & 0.079 & 0.301 & -0.017 & 0.043 & 0.102 & 0.078 & 0.081 & 0.332 & 0.04 & 0.041 & 0.234 \\
\hline & {$[1.04]$} & {$[1.14]$} & {$[1.67]^{*}$} & {$[0.63]$} & {$[0.94]$} & {$[0.67]$} & {$[1.30]$} & {$[0.80]$} & {$[1.96]^{*}$} & [1.17] & {$[0.80]$} & {$[2.13]^{* *}$} \\
\hline \multirow[t]{2}{*}{ Constant } & -0.018 & -0.154 & 0.424 & -0.071 & -0.139 & 0.024 & 0.274 & -0.061 & 0.068 & 0.015 & -0.154 & 0.491 \\
\hline & {$[0.21]$} & [1.39] & {$[1.85]^{*}$} & {$[1.38]$} & {$[1.57]$} & {$[0.15]$} & {$[2.81] * * *$} & {$[0.44]$} & {$[0.36]$} & {$[0.16]$} & [1.39] & {$[2.87] * * *$} \\
\hline Industry Dummies & Yes & Yes & Yes & Yes & Yes & Yes & Yes & Yes & Yes & Yes & Yes & Yes \\
\hline Year Dummies & Yes & Yes & Yes & Yes & Yes & Yes & Yes & Yes & Yes & Yes & Yes & Yes \\
\hline Observations & 3,982 & 2,830 & 500 & 3,800 & 2,706 & 479 & 2,118 & 1,591 & 325 & 4,419 & 2,830 & 524 \\
\hline R-squared & 0.19 & 0.19 & 0.24 & 0.17 & 0.15 & 0.28 & 0.22 & 0.24 & 0.26 & 0.46 & 0.19 & 0.42 \\
\hline
\end{tabular}


Table 10: Pooled OLS Regression by Industry Type

This table incorporates Pooled OLS regression with sector breakdown. Concentration (sum of the 5 largest firms' total sales divided by the total sales in the industry) is a measure if industry concentration. Robust $t$ statistics are in brackets. Significance at $1 \%, 5 \%$ and $10 \%$ levels is represented as ***,**,* respectively.

\begin{tabular}{|c|c|c|c|c|c|c|c|c|c|c|c|c|}
\hline \multirow{3}{*}{ - } & \multicolumn{12}{|c|}{ Pooled } \\
\hline & \multicolumn{3}{|c|}{ Debt/Asset } & \multicolumn{3}{|c|}{ STDebt/Asset } & \multicolumn{3}{|c|}{ LTDebt/Asset } & \multicolumn{3}{|c|}{ Payables/Asset } \\
\hline & $\begin{array}{l}\text { Manufacturin } \\
\mathrm{g}\end{array}$ & Services & $\begin{array}{l}\text { Agricultur } \\
\mathrm{e}\end{array}$ & $\begin{array}{l}\text { Manufact } \\
\text { uring }\end{array}$ & Services & $\begin{array}{l}\text { Agricultur } \\
\mathrm{e}\end{array}$ & $\begin{array}{l}\text { Manufact } \\
\text { uring }\end{array}$ & Services & $\begin{array}{l}\text { Agricul } \\
\text { ture }\end{array}$ & $\begin{array}{l}\text { Manufact } \\
\text { uring }\end{array}$ & Services & $\begin{array}{l}\text { Agricultur } \\
\mathrm{e}\end{array}$ \\
\hline Small & $\begin{array}{l}0.099 \\
{[3.28]^{* * *}}\end{array}$ & $\begin{array}{l}-0.01 \\
{[0.29]}\end{array}$ & $\begin{array}{l}-0.035 \\
{[0.66]}\end{array}$ & $\begin{array}{l}0.07 \\
{[3.17]^{* * *}}\end{array}$ & $\begin{array}{l}0.039 \\
{[1.57]}\end{array}$ & $\begin{array}{l}0.003 \\
{[0.08]}\end{array}$ & $\begin{array}{l}0.039 \\
{[1.36]}\end{array}$ & $\begin{array}{l}-0.096 \\
{[2.13]^{* *}}\end{array}$ & $\begin{array}{l}-0.051 \\
{[0.96]}\end{array}$ & $\begin{array}{l}0.067 \\
{[2.40]^{* *}}\end{array}$ & $\begin{array}{l}0.07 \\
{[2.01]^{* *}}\end{array}$ & $\begin{array}{l}-0.006 \\
{[0.21]}\end{array}$ \\
\hline Medium & 0.076 & 0.002 & 0 & 0.057 & 0.034 & 0 & 0.025 & -0.065 & 0 & 0.038 & 0.061 & 0 \\
\hline & {$[3.28]^{* * *}$} & {$[0.06]$} & {$[]$.} & {$[3.36]^{* * *}$} & [1.60] & {$[]$.} & {$[1.20]$} & [1.63] & {$[]$.} & {$[1.72]^{*}$} & {$[2.01]^{* *}$} & {$[]$.} \\
\hline Foreign & 0.026 & -0.003 & 0.371 & 0 & -0.011 & 0.134 & 0.061 & 0.037 & $\begin{array}{l}0.295 \\
{[2.19]^{*}}\end{array}$ & -0.046 & -0.052 & -0.141 \\
\hline & {$[1.77]^{*}$} & {$[0.25]$} & {$[2.69]^{* * *}$} & {$[0.02]$} & {$[1.12]$} & {$[1.35]$} & {$[4.23]^{* * *}$} & {$[2.15]^{* *}$} & $*$ & {$[3.85]^{* * *}$} & {$[3.61]^{* * *}$} & {$[2.13]^{* *}$} \\
\hline Government & $\begin{array}{l}-0.103 \\
{[6.98]^{* * *}}\end{array}$ & $\begin{array}{l}-0.133 \\
{[8.44]^{* * *}}\end{array}$ & $\begin{array}{l}-0.046 \\
{[0.77]}\end{array}$ & $\begin{array}{l}-0.052 \\
{[5.03]^{* * *}}\end{array}$ & $\begin{array}{l}-0.05 \\
{[4.81]^{* * *}}\end{array}$ & $\begin{array}{l}-0.005 \\
{[0.16]}\end{array}$ & $\begin{array}{l}-0.061 \\
{[4.75]^{* * *}}\end{array}$ & $\begin{array}{l}-0.109 \\
{[5.56]^{* * *}}\end{array}$ & $\begin{array}{l}-0.071 \\
{[1.82]^{*}}\end{array}$ & $\begin{array}{l}-0.077 \\
{[6.98]^{* * *}}\end{array}$ & $\begin{array}{l}-0.151 \\
{[9.51]^{* * *}}\end{array}$ & $\begin{array}{l}-0.141 \\
{[3.28]^{* * *}}\end{array}$ \\
\hline Wielkopolskie & $\begin{array}{l}-0.003 \\
{[0.22]}\end{array}$ & $\begin{array}{l}0.012 \\
{[0.86]}\end{array}$ & $\begin{array}{l}0.012 \\
{[0.39]}\end{array}$ & $\begin{array}{l}-0.008 \\
{[0.73]}\end{array}$ & $\begin{array}{l}0.008 \\
{[0.68]}\end{array}$ & $\begin{array}{l}0.011 \\
{[0.55]}\end{array}$ & $\begin{array}{l}-0.005 \\
{[0.36]}\end{array}$ & $\begin{array}{l}-0.011 \\
{[0.94]}\end{array}$ & $\begin{array}{l}0.003 \\
{[0.13]}\end{array}$ & $\begin{array}{l}0.02 \\
{[1.64]}\end{array}$ & $\begin{array}{l}-0.016 \\
{[0.99]}\end{array}$ & $\begin{array}{l}-0.016 \\
{[0.82]}\end{array}$ \\
\hline Mazoweicke & $\begin{array}{l}-0.005 \\
{[0.31]}\end{array}$ & $\begin{array}{l}0.013 \\
{[1.20]}\end{array}$ & $\begin{array}{l}-0.078 \\
{[1.44]}\end{array}$ & $\begin{array}{l}-0.008 \\
{[0.70]}\end{array}$ & $\begin{array}{l}-0.009 \\
{[1.19]}\end{array}$ & $\begin{array}{l}-0.025 \\
{[0.56]}\end{array}$ & $\begin{array}{l}0.005 \\
{[0.33]}\end{array}$ & $\begin{array}{l}0.044 \\
{[3.22]^{* * *}}\end{array}$ & $\begin{array}{l}-0.069 \\
{[1.36]}\end{array}$ & $\begin{array}{l}0.015 \\
{[1.14]}\end{array}$ & $\begin{array}{l}-0.03 \\
{[2.51]^{* *}}\end{array}$ & $\begin{array}{l}0.067 \\
{[1.36]}\end{array}$ \\
\hline Slaskie & $\begin{array}{l}-0.056 \\
{[3.95]^{* * *}}\end{array}$ & $\begin{array}{l}-0.014 \\
{[0.98]}\end{array}$ & $\begin{array}{l}0 \\
{[.]}\end{array}$ & $\begin{array}{l}-0.034 \\
{[3.28]^{* * *}}\end{array}$ & $\begin{array}{l}-0.01 \\
{[0.85]}\end{array}$ & $\begin{array}{l}0 \\
0 .]\end{array}$ & $\begin{array}{l}-0.027 \\
{[1.84]^{*}}\end{array}$ & $\begin{array}{l}-0.007 \\
{[0.45]}\end{array}$ & $\begin{array}{l}0 \\
0.1\end{array}$ & $\begin{array}{l}0.021 \\
{[1.35]}\end{array}$ & $\begin{array}{l}-0.021 \\
{[1.21]}\end{array}$ & $\begin{array}{l}{[1.00]} \\
{[.]}\end{array}$ \\
\hline Ln Sales & $\begin{array}{l}0.033 \\
{[4.05]^{* * *}}\end{array}$ & $\begin{array}{l}0.018 \\
{[2.81]^{* * *}}\end{array}$ & $\begin{array}{l}-0.032 \\
{[1.11]}\end{array}$ & $\begin{array}{l}0.024 \\
{[4.49]^{* * *}}\end{array}$ & $\begin{array}{l}0.025 \\
{[5.12]^{* * *}}\end{array}$ & $\begin{array}{l}-0.007 \\
{[0.32]}\end{array}$ & $\begin{array}{l}0.007 \\
{[0.91]}\end{array}$ & $\begin{array}{l}-0.015 \\
{[1.80]^{*}}\end{array}$ & $\begin{array}{l}-0.029 \\
{[1.49]}\end{array}$ & $\begin{array}{l}0.031 \\
{[4.89]^{* * *}}\end{array}$ & $\begin{array}{l}0.029 \\
{[4.64]^{* * *}}\end{array}$ & $\begin{array}{l}0.027 \\
{[1.86]^{*}}\end{array}$ \\
\hline Ln Age & {$[0.06]$} & $\begin{array}{l}-0.039 \\
{[6.50]^{* * *}}\end{array}$ & $\begin{array}{l}0.008 \\
{[0.57]}\end{array}$ & $\begin{array}{l}0.004 \\
{[0.89]}\end{array}$ & $\begin{array}{l}-0.018 \\
{[4.23]^{* * *}}\end{array}$ & $\begin{array}{l}0.015 \\
{[1.55]}\end{array}$ & $\begin{array}{l}-0.009 \\
{[1.42]}\end{array}$ & $\begin{array}{l}-0.036 \\
{[5.06]^{* * *}}\end{array}$ & $\begin{array}{l}-0.008 \\
{[0.57]}\end{array}$ & $\begin{array}{l}-0.026 \\
{[5.09]^{* * *}}\end{array}$ & $\begin{array}{l}-0.03 \\
{[5.05]^{* * *}}\end{array}$ & $\begin{array}{l}-0.008 \\
{[0.95]}\end{array}$ \\
\hline ROA & $\begin{array}{l}-0.209 \\
{[6.27]^{* * *}}\end{array}$ & $\begin{array}{l}-0.133 \\
{[4.44] * * *}\end{array}$ & $\begin{array}{l}-0.467 \\
{[2.74] * * *}\end{array}$ & $\begin{array}{l}-0.161 \\
{[6.15]^{* * *}}\end{array}$ & $\begin{array}{l}-0.099 \\
{[4.03]^{* * *}}\end{array}$ & $\begin{array}{l}-0.278 \\
{[2.50]^{* *}}\end{array}$ & $\begin{array}{l}-0.067 \\
{[1.95]^{*}}\end{array}$ & $\begin{array}{l}-0.027 \\
{[0.76]}\end{array}$ & $\begin{array}{l}-0.202 \\
{[0.97]}\end{array}$ & $\begin{array}{l}-0.284 \\
{[9.00]^{* * *}}\end{array}$ & $\begin{array}{l}-0.452 \\
{[13.48]^{* *}} \\
*\end{array}$ & -0.507 \\
\hline Fixed Asset/Asset & 0.055 & 0.178 & -0.059 & -0.079 & -0.01 & -0.135 & 0.128 & 0.242 & 0.125 & $\begin{array}{l}-0.295 \\
{[13.63]^{* *}}\end{array}$ & $\begin{array}{l}-0.416 \\
{[19.36]^{* *}}\end{array}$ & -0.161 \\
\hline & {$[2.08]^{* *}$} & {$[7.30] * * *$} & {$[0.49]$} & {$[4.39]^{* * *}$} & {$[0.75]$} & {$[1.72]^{*}$} & {$[4.47]^{* * *}$} & {$[7.90]^{* * *}$} & [1.10] & $*$ & $*$ & {$[2.12]^{* *}$} \\
\hline Sales Growth & $\begin{array}{l}0.014 \\
{[2.59]^{* * *}}\end{array}$ & $\begin{array}{l}0.001 \\
{[0.12]}\end{array}$ & $\begin{array}{l}0.065 \\
{[1.97]^{*}}\end{array}$ & $\begin{array}{l}0.002 \\
{[0.48]}\end{array}$ & $\begin{array}{l}-0.002 \\
{[0.64]}\end{array}$ & $\begin{array}{l}0.016 \\
{[0.62]}\end{array}$ & $\begin{array}{l}0.014 \\
{[2.61]^{* * *}}\end{array}$ & $\begin{array}{l}0.01 \\
{[1.51]}\end{array}$ & $\begin{array}{l}0.036 \\
{[0.96]}\end{array}$ & $\begin{array}{l}0.015 \\
{[4.21]^{* * *}}\end{array}$ & $\begin{array}{l}-0.002 \\
{[0.35]}\end{array}$ & $\begin{array}{l}0.064 \\
{[2.94]^{* * *}}\end{array}$ \\
\hline Depreciation/Asset & $\begin{array}{l}0.12 \\
{[0.76]}\end{array}$ & $\begin{array}{l}-0.018 \\
{[0.17]}\end{array}$ & $\begin{array}{l}-0.239 \\
{[0.22]}\end{array}$ & $\begin{array}{l}0.055 \\
{[0.47]}\end{array}$ & $\begin{array}{l}0.148 \\
{[2.10]^{* *}}\end{array}$ & $\begin{array}{l}-0.611 \\
{[0.93]}\end{array}$ & $\begin{array}{l}0.172 \\
{[1.00]}\end{array}$ & $\begin{array}{l}-0.25 \\
{[2.06]^{* *}}\end{array}$ & $\begin{array}{l}0.218 \\
{[0.26]}\end{array}$ & $\begin{array}{l}-0.161 \\
{[1.36]}\end{array}$ & $\begin{array}{l}-0.176 \\
{[1.65]^{*}}\end{array}$ & $\begin{array}{l}0.675 \\
{[0.80]}\end{array}$ \\
\hline Concentration & $\begin{array}{l}-0.211 \\
{[3.99]^{* * *}}\end{array}$ & $\begin{array}{l}-0.089 \\
{[2.31]^{* *}}\end{array}$ & $\begin{array}{l}0 \\
{[.]}\end{array}$ & $\begin{array}{l}-0.151 \\
{[3.81]^{* * *}}\end{array}$ & $\begin{array}{l}-0.15 \\
{[6.38]^{* * *}}\end{array}$ & $\begin{array}{l}0 \\
{[.]}\end{array}$ & $\begin{array}{l}-0.045 \\
{[0.94]}\end{array}$ & $\begin{array}{l}0.078 \\
{[1.55]}\end{array}$ & $\begin{array}{l}0 \\
{[.]}\end{array}$ & $\begin{array}{l}0.116 \\
{[3.11]^{* * *}}\end{array}$ & $\begin{array}{l}-0.069 \\
{[1.98]^{* *}}\end{array}$ & $\begin{array}{l}0 \\
{[.]}\end{array}$ \\
\hline Constant & $\begin{array}{l}-0.12 \\
{[1.24]}\end{array}$ & $\begin{array}{l}0.095 \\
{[1.14]}\end{array}$ & $\begin{array}{l}0.445 \\
{[1.59]}\end{array}$ & $\begin{array}{l}-0.055 \\
{[0.82]}\end{array}$ & $\begin{array}{l}-0.055 \\
{[0.87]}\end{array}$ & $\begin{array}{l}0.195 \\
{[0.97]}\end{array}$ & $\begin{array}{l}-0.015 \\
{[0.16]}\end{array}$ & $\begin{array}{l}0.318 \\
{[2.92]^{* * *}}\end{array}$ & $\begin{array}{l}0.332 \\
{[1.69]^{*}}\end{array}$ & $\begin{array}{l}0.094 \\
{[1.18]}\end{array}$ & $\begin{array}{l}0.358 \\
{[4.32]^{* * *}}\end{array}$ & $\begin{array}{l}0.092 \\
{[0.65]}\end{array}$ \\
\hline Industry Dummies & Yes & Yes & Yes & Yes & Yes & Yes & Yes & Yes & Yes & Yes & Yes & Yes \\
\hline Year Dummies & No & No & No & No & No & No & No & No & No & No & No & No \\
\hline Observations & 3,270 & 3,843 & 188 & 3,120 & 3,675 & 180 & 1,991 & 1,887 & 149 & 3,473 & 4,295 & 188 \\
\hline R-squared & 0.17 & 0.18 & 0.34 & 0.14 & 0.16 & 0.25 & 0.16 & 0.24 & 0.37 & 0.31 & 0.47 & 0.55 \\
\hline
\end{tabular}


Table 11: Pooled OLS Regression. Financing, Corporate Governance

This table incorporates Pooled OLS regression with two alternative subsets of dummy variables: the first identifies firms with majority holding (greater than $50 \%$ )- owned by either a foreign or a private domestic investor- and the second identifies majorities held by the state, an individual or an industrial shareholder. Robust $t$ statistics in brackets. Significance at $1 \%, 5 \%$ and $10 \%$ levels is represented as $* * *, * *, *$ respectively.

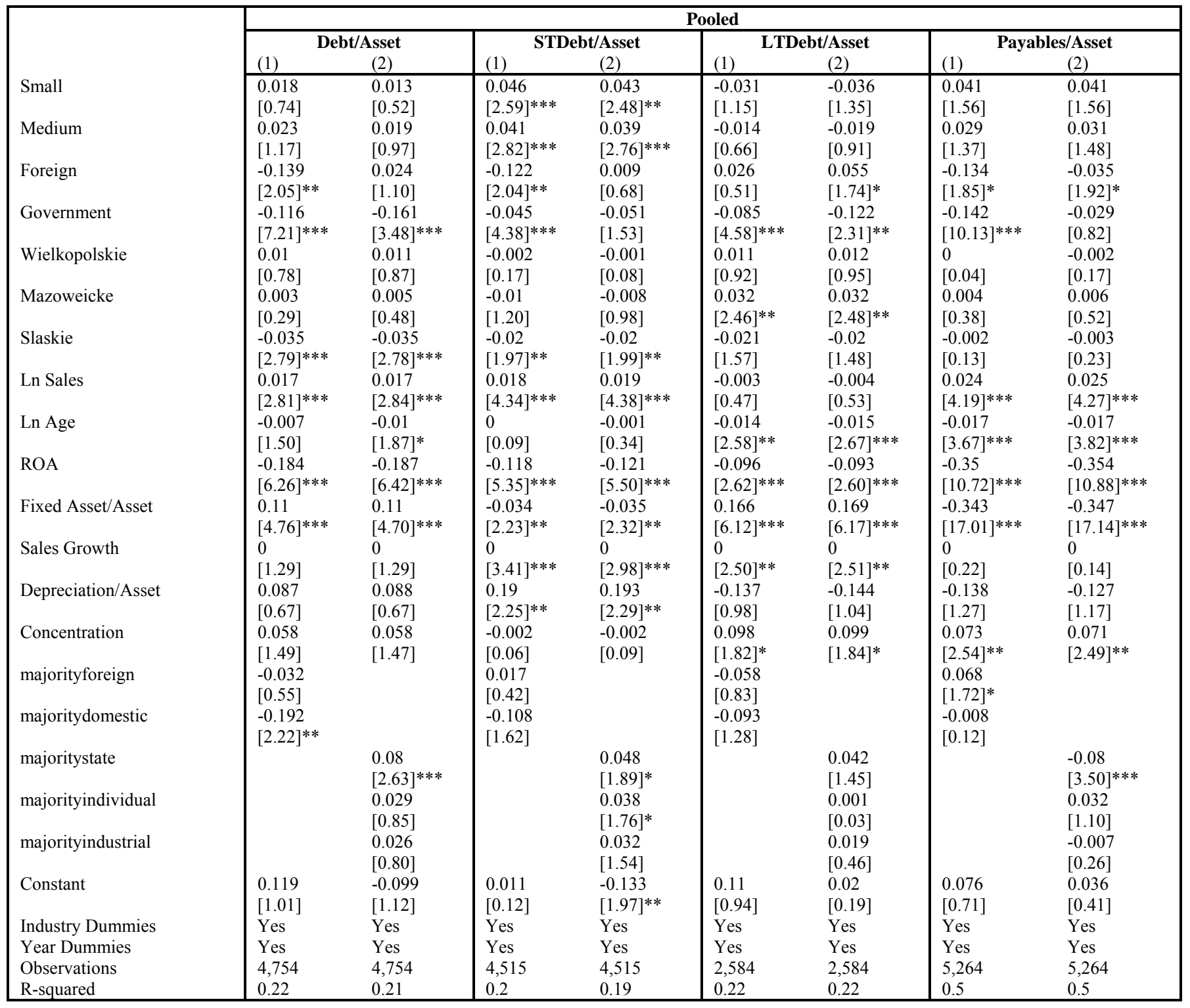

